\title{
Journal of Iberian Geology
}

\section{The importance of sequential partial melting and fractional crystallization in the generation of syn-D3 Variscan two-mica granites from the Carrazeda de Ansiães area, northern Portugal \\ --Manuscript Draft--}

\begin{tabular}{|l|l|l|}
\hline Manuscript Number: & JIBG-D-20-00067R2 & \\
\hline Full Title: & $\begin{array}{l}\text { The importance of sequential partial melting and fractional crystallization in the } \\
\text { generation of syn-D3 Variscan two-mica granites from the Carrazeda de Ansiães area, } \\
\text { northern Portugal }\end{array}$ \\
\hline Article Type: & S.I. : New developments in Geochemistry. A tribute to Carmen Galindo \\
\hline Funding Information: & $\begin{array}{l}\text { EU SOCFAC facility } \\
\text { (HPRI-1999-CT-00108) }\end{array}$ & Dr. Rui José dos Santos Teixeira \\
\hline $\begin{array}{l}\text { PhD grant from FCT - Fundação para a } \\
\text { Ciência e a Tecnologia, Portugal } \\
\text { (SFRH/BD/17246/2004) }\end{array}$ & Dr. Rui José dos Santos Teixeira \\
\hline $\begin{array}{l}\text { Pole of the Geosciences Centre (CGeo) } \\
\text { through FCT - Portuguese Foundation for } \\
\text { Sciences and Technology } \\
\text { (Projects UIDB/00073/2020 and } \\
\text { UIDP/00073/2020) }\end{array}$ & Dr. Rui José dos Santos Teixeira \\
\hline
\end{tabular}

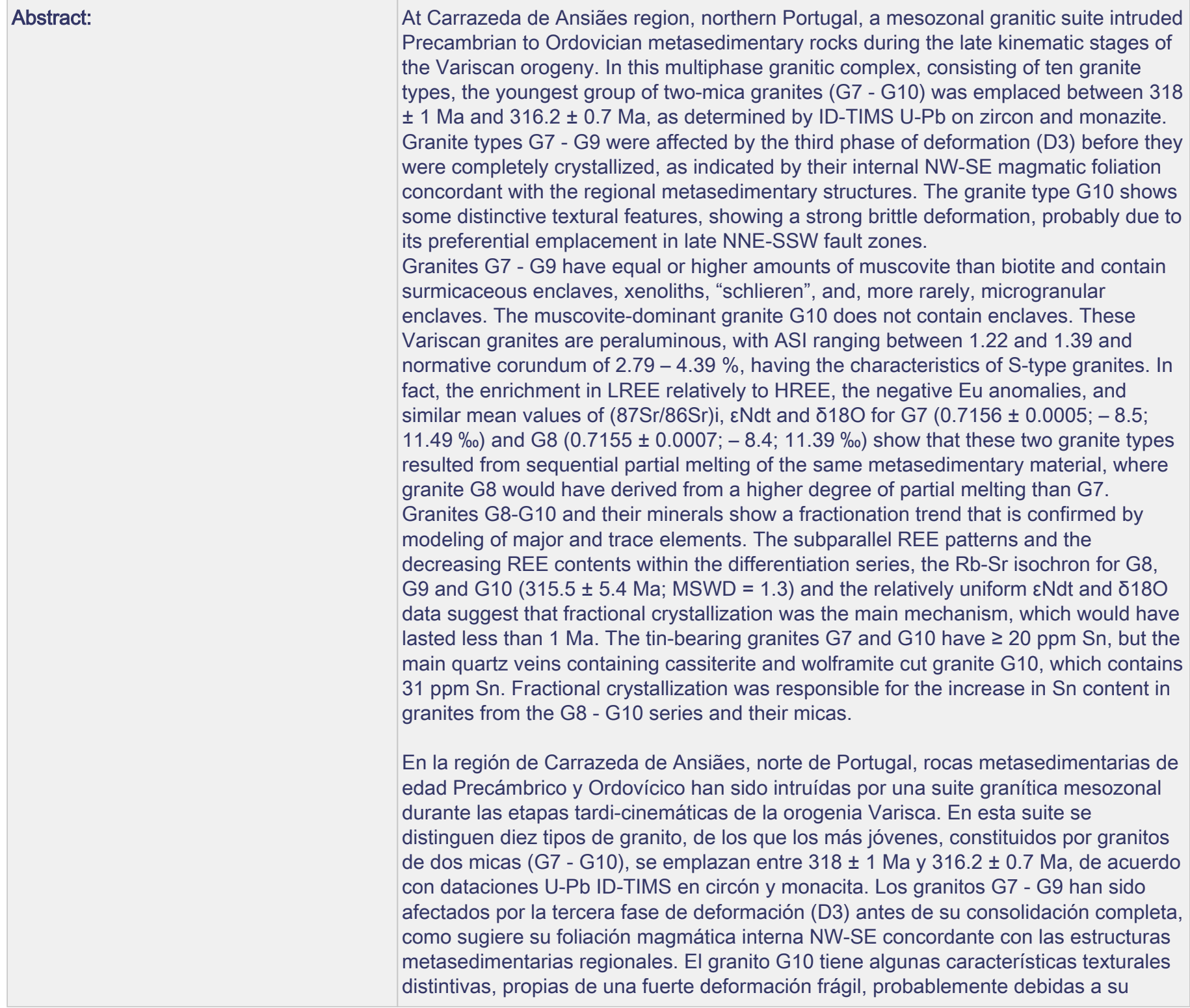


emplazamiento preferente en zonas de fallas tardías con dirección NNE-SSW.

Los granitos G7 - G9 tienen cantidades de moscovita iguales o mayores que las de biotita y contienen enclaves "surmicaceous", xenolitos, "schlieren" y, raras veces, enclaves microgranudos. El granito G10 predominantemente moscovítico no contiene enclaves. Estos granitos variscos son peralumínicos, con valores de ASI entre 1.22 y 1.39 , y de corindón normativo entre $2.79-4.39 \%$, y presentan características típicas de granitos de tipo S. De hecho, el enriquecimiento en LREE con respecto a las HREE, las anomalías negativas de Eu y valores medios similares de (87Sr/86Sr)i, عNdt y $\delta 180$ para G7 $(0.7156 \pm 0.0005 ;-8.5 ; 11.49 \%)$ y G8 $(0.7155 \pm 0.0007 ;-8.4 ; 11.39$ $\%$ ) muestran que estos dos tipos de granito son el producto de la fusión parcial secuencial del mismo material metasedimentario, del que el granito G8 correspondería a una mayor tasa de fusión parcial que el granito G7.

Los granitos G8-G10 y sus minerales muestran una evolución por fraccionación que se puede confirmar mediante la modelización de elementos mayores y traza. Los espectros de REE subparalelos y la disminución de sus contenidos con la diferenciación, la isócrona Rb-Sr para G8, G9 y G10 (315.5 — 5.4 Ma; MSWD = 1.3) y los valores relativamente uniformes de $\varepsilon N d t$ y $\delta 180$ sugieren que la cristalización fraccionada ha sido el principal mecanismo implicado, y habría tenido una duración inferior a $1 \mathrm{Ma}$.

Los granitos especializados estanníferos G7 y G10 tienen contenidos de $\mathrm{Sn} \geq 20$ ppm, pero los principales filones de cuarzo con casiterita y wolframita cortan al granito G10, que contiene $31 \mathrm{ppm}$ de Sn. La cristalización fraccionada ha sido responsable del aumento del contenido de $\mathrm{Sn}$ en los granitos de la serie G8 - G10 y de sus micas.

\section{Corresponding Author:}

Rui José dos Santos Teixeira

Universidade de Tras-os-Montes e Alto Douro Escola de Ciencias da Vida e do

Ambiente

Vila Real, Vila Real PORTUGAL

Corresponding Author Secondary Information:

\section{Corresponding Author's Institution:}

Universidade de Tras-os-Montes e Alto Douro Escola de Ciencias da Vida e do Ambiente

\section{Corresponding Author's Secondary} Institution:

First Author:

Rui José dos Santos Teixeira

First Author Secondary Information:

Order of Authors:

\begin{tabular}{|l|}
\hline Rui José dos Santos Teixeira \\
\hline Ana Margarida Ribeiro Neiva \\
\hline Maria Elisa Preto Gomes \\
\hline Fernando Corfu \\
\hline Andrés Cuesta \\
\hline Ian W. Croudace \\
\hline
\end{tabular}

Order of Authors Secondary Information:

Author Comments:

\section{Dear Editors,}

I'm submitting the revised manuscript according to the last suggestions of the reviewer, which helped very much to improve the paper "The importance of sequential partial melting and fractional crystallization in the generation of syn-D3 Variscan two-mica granites from the Carrazeda de Ansiães area, northern Portugal". We have implemented all the suggested modifications, which are marked in blue in the annotated version of the revised manuscript. We have also made some other minor corrections in the manuscript, as well as in the Figure 6 and respective caption (marked in blue).

We are very grateful for your help, 
1 The importance of sequential partial melting and fractional crystallization in the generation of syn-

$2 D_{3}$ Variscan two-mica granites from the Carrazeda de Ansiães area, northern Portugal

3

4 R. J. S. Teixeira ${ }^{a^{*}}$, A. M. R. Neiva ${ }^{\dagger}$, M. E. P. Gomes ${ }^{\mathrm{a}}$, F. Corfu ${ }^{\mathrm{b}}$, A. Cuesta ${ }^{\text {c }}$, I. W. Croudace ${ }^{\mathrm{d}}$

5

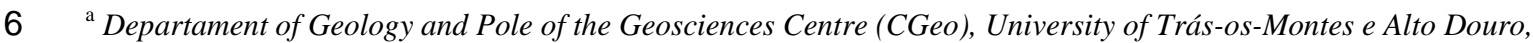

7 UTAD, Quinta dos Prados, 5000-801, Vila Real, Portugal

$8{ }^{\mathrm{b}}$ Department of Geosciences and CEED, University of Oslo, PO Box 1047 Blindern, N-0316 Oslo, Norway

$9 \quad{ }^{\mathrm{c}}$ Department of Geology, University of Oviedo, C/ Jesús Arias de Velasco s/n, 33005 Oviedo, Spain

$10 \mathrm{~d}$ Ocean and Earth Science, National Oceanography Centre, Southampton, University of Southampton, European

11 Way, Southampton SO14 3ZH, United Kingdom

Abstract

At Carrazeda de Ansiães region, northern Portugal, a mesozonal granitic suite intruded Precambrian to Ordovician metasedimentary rocks during the late kinematic stages of the Variscan orogeny. In this multiphase granitic complex, consisting of ten granite types, the youngest group of two-mica granites (G7 - G10) was emplaced between $318 \pm 1$ Ma and 316.2 $\pm 0.7 \mathrm{Ma}$, as determined by ID-TIMS U-Pb on zircon and monazite. Granite types G7 - G9 were affected by the third phase of deformation $\left(\mathrm{D}_{3}\right)$ before they were completely crystallized, as indicated by their internal NW-SE magmatic foliation concordant with the regional metasedimentary structures. The granite type G10 shows some distinctive textural features, showing a strong brittle deformation, probably due to its preferential emplacement in late NNE-SSW fault zones.

Granites G7 - G9 have equal or higher amounts of muscovite than biotite and contain surmicaceous enclaves, xenoliths, "schlieren", and, more rarely, microgranular enclaves. The muscovite-dominant granite G10 does not contain enclaves. These Variscan granites are peraluminous, with ASI ranging between 1.22 and 1.39 and normative corundum of $2.79-4.39 \%$, having the characteristics of S-type granites. In fact, the enrichment in LREE relatively to HREE, the negative Eu anomalies, and similar mean values of $\left({ }^{87} \mathrm{Sr} /{ }^{86} \mathrm{Sr}\right){ }_{\mathrm{i}}, \varepsilon_{\mathrm{Nd}}$ and $\delta^{18} \mathrm{O}$ for $\mathrm{G} 7(0.7156 \pm 0.0005$;

\footnotetext{
${ }^{*}$ Corresponding author. Tel.: +351 259350364; Fax.: +351 259350480

E-mail address: rteixeir@utad.pt (R. J. S. Teixeira)

${ }^{\dagger}$ Deceased in $3^{\text {rd }}$ May 2019.
} 
30 Granites G8-G10 and their minerals show a fractionation trend that is confirmed by modeling of major and trace 60 elements. The subparallel REE patterns and the decreasing REE contents within the differentiation series, the $\mathrm{Rb}-\mathrm{Sr}$ isochron for $\mathrm{G} 8, \mathrm{G} 9$ and $\mathrm{G} 10(315.5 \pm 5.4 \mathrm{Ma} ; \mathrm{MSWD}=1.3)$ and the relatively uniform $\varepsilon \mathrm{Nd}_{\mathrm{t}}$ and $\delta^{18} \mathrm{O}$ data suggest that fractional crystallization was the main mechanism, which would have lasted less than $1 \mathrm{Ma}$. The tin-bearing granites G7 and G10 have $\geq 20 \mathrm{ppm} \mathrm{Sn}$, but the main quartz veins containing cassiterite and wolframite cut granite G10, which contains $31 \mathrm{ppm}$ Sn. Fractional crystallization was responsible for the increase in Sn content in granites from the G8 - G10 series and their micas.

Keywords: S-type granites; U-Pb zircon and monazite ages; Isotopic data; Sequential partial melting; Fractional crystallization; Tin

\section{Resumen}

En la región de Carrazeda de Ansiães, norte de Portugal, rocas metasedimentarias de edad Precámbrico y Ordovícico han sido intruídas por una suite granítica mesozonal durante las etapas tardi-cinemáticas de la orogenia Varisca. En esta suite se distinguen diez tipos de granito, de los que los más jóvenes, constituidos por granitos de dos micas (G7 G10), se emplazan entre $318 \pm 1$ Ma y 316.2 \pm 0.7 Ma, de acuerdo con dataciones U-Pb ID-TIMS en circón y monacita. Los granitos G7 - G9 han sido afectados por la tercera fase de deformación $\left(\mathrm{D}_{3}\right)$ antes de su consolidación completa, como sugiere su foliación magmática interna NW-SE concordante con las estructuras metasedimentarias regionales. El granito G10 tiene algunas características texturales distintivas, propias de una fuerte deformación frágil, probablemente debidas a su emplazamiento preferente en zonas de fallas tardías con dirección NNE-SSW. Los granitos G7 - G9 tienen cantidades de moscovita iguales o mayores que las de biotita y contienen enclaves "surmicaceous", xenolitos, "schlieren" y, raras veces, enclaves microgranudos. El granito G10 predominantemente moscovítico no contiene enclaves. Estos granitos variscos son peralumínicos, con valores de ASI entre 1.22 y 1.39 , y de corindón normativo entre 2.79 - 4.39\%, y presentan características típicas de granitos de tipo S. De hecho, el enriquecimiento en LREE con respecto a las HREE, las anomalías negativas de Eu y valores medios similares de $\left({ }^{87} \mathrm{Sr} /{ }^{86} \mathrm{Sr}\right)_{\mathrm{i}}, \varepsilon \mathrm{Nd}_{\mathrm{t}}$ y $\delta^{18} \mathrm{O}$ para G7 $(0.7156 \pm 0.0005 ;-8.5 ; 11.49 \%$ y G8 $(0.7155 \pm 0.0007 ;-8.4 ; 11.39 \%$ muestran que estos dos tipos de granito son el producto de la fusión parcial secuencial del mismo material metasedimentario,

7 del que el granito G8 correspondería a una mayor tasa de fusión parcial que el granito G7.

8 Los granitos G8-G10 y sus minerales muestran una evolución por fraccionación que se puede confirmar mediante la 9 modelización de elementos mayores y traza. Los espectros de REE subparalelos y la disminución de sus contenidos con la diferenciación, la isócrona Rb-Sr para G8, G9 y G10 (315.5 —5.4 Ma; MSWD = 1.3) y los valores 
61 relativamente uniformes de $\varepsilon \mathrm{Nd}_{\mathrm{t}}$ y $\delta^{18} \mathrm{O}$ sugieren que la cristalización fraccionada ha sido el principal mecanismo 62 implicado, y habría tenido una duración inferior a 1 Ma.

63 Los granitos especializados estanníferos G7 y G10 tienen contenidos de $\mathrm{Sn} \geq 20$ ppm, pero los principales filones de cuarzo con casiterita y wolframita cortan al granito G10, que contiene 31 ppm de Sn. La cristalización fraccionada ha sido responsable del aumento del contenido de Sn en los granitos de la serie G8 - G10 y de sus micas.

66

Palabras clave: Granitos de tipo S; Edades U-Pb en circón y monacita; Datos isotópicos; Fusión parcial secuencial; 


\section{Introduction}

Most granitoid plutons in the Central Iberian Zone of the Iberian Massif (Fig. 1a) were formed and emplaced during the last ductile regional Variscan deformation phase $\left(\mathrm{D}_{3}\right)($ e.g. Ferreira et al., 1987; Azevedo and Nolan, 1998; Dias et al., 2002; Bea et al., 2003; Valle Aguado et al., 2005; GutiérrezAlonso et al., 2018). At Carrazeda de Ansiães area, northern Portugal, this geological event is well marked by a suite of ten different S-type granite units, mainly derived by partial melting of metasedimentary rocks, followed by fractional crystallization or, more rarely, segregated from a sequential melting process (Teixeira, 2008). This paper reports the geology, mineralogy, petrology, geochemistry and isotopic compositions $\left(\mathrm{Rb}-\mathrm{Sr}, \mathrm{Sm}-\mathrm{Nd}, \delta^{18} \mathrm{O}\right)$ of the four youngest granite types of the granitic suite of Carrazeda de Ansiães, belonging to Group II (G7, G8 and G9) and Group III (G10) as defined by Teixeira (2008). The aim is to understand the processes responsible for their compositional variability and also the origin of high concentrations of tin in granites G7 and G10 and their micas. In addition, this study also documents the challenging task of determining the crystallization ages of the four aforementioned granites by ID-TIMS U-Pb geochronology, in order to verify that they post-date the early syn- $\mathrm{D}_{3}$ granites described by Teixeira et al. (2012a) in this area, as it is inferred by the geological field relations.

\section{Geological setting}

\subsection{General features}

The Carrazeda de Ansiães area (Northern Portugal) lies in the autochthonous segment of the Central Iberian Zone of the Iberian Massif that is dominated by a thick sequence of Precambrian to Lower Paleozoic metasediments deposited onto the ancient margin of Gondwana (Fig. 1; Pereira et al., 2018). Lower Ordovician volcanic / hypabyssal rocks also occur (e.g. Coke et al., 2011; Teixeira et al., 2013a, 2015). The metasedimentary sequence is known as Dúrico-Beirão Super Group and is subdivided in two groups: Douro Group and Beiras Group (Oliveira et al., 1992). Large volumes of granitic rocks were emplaced in the Central Iberian Zone (CIZ) metasediments and ortho-derived rocks before, during and after the third phase of deformation of the Variscan orogeny $\left(\mathrm{D}_{3}\right)$, in a period constrained between ca. 347 - $337 \mathrm{Ma}$ and ca. $290 \mathrm{Ma}$, as indicated by U-Pb data of zircon and monazite (e.g. Valle Aguado et al., 2005; Martins et al., 2009, 2013; Neiva et al., 2009; Teixeira et al., 2012a; Gutiérrez-Alonso et al., 2018). 

core of the Vila Real - Torre de Moncorvo antiform formed during the $\mathrm{D}_{1}$ and $\mathrm{D}_{3}$ deformation phases

The mesozonal intrusive granitic suite of Carrazeda de Ansiães intruded along the NW-trending (Silva et al., 1989; Fig. 1). This is in accordance with the typical spatial distribution of several groups of syn- $\mathrm{D}_{3}$ granites in the Portuguese sector of Central Iberian Zone, occurring along important NW-SE alignments that correspond either to the cores of $\mathrm{D}_{3}$ antiforms or to transcurrent shear zones that would have accommodated the horizontal shortening produced in the final stages of the continental collision (Ferreira et al., 1987; Dias and Coke, 2006).

Based on field relationships and petrographic data it is possible to distinguish different types of granites in the Carrazeda de Ansiães area (Fig. 1b) that chronologically are arranged as follows: Group I, including granite types G1 to G6; Group II, formed by granites G7 to G9; and Group III, constituted only by granite G10.

Group I granites are anisotropic and show evidence of a magmatic foliation that was superposed by a more intense subparallel foliation formed in a ductile-brittle regime (Teixeira et al., 2012a). The internal structure of these granites (foliation) is concordant to those of the host metasedimentary rocks, showing a predominant NW-SE direction. The structural features suggest that granites of Group I would already have been consolidated (or at least in a sub-magmatic state) when they were affected by the third phase of deformation $\left(\mathrm{D}_{3}\right)$ (Teixeira et al., 2011, 2012a).

Group II granites were apparently deformed by $\mathrm{D}_{3}$ before being completely crystallized, which explains the occurrence of an internal NW-SE magmatic foliation, concordant with the structure of host metasediments. This magmatic foliation, more or less penetrative, is given by the orientation of feldspar phenocrysts, biotite (Fig. 2a), rarely by muscovite and, in the case of granite G8, by its abundant surmicaceous enclaves and xenoliths (Fig. 2b). The dominant magmatic nature of the structure of these granites is mainly recognized by the fact that the euhedral feldspar phenocrysts and the quartz crystals of the matrix are apparently undeformed (Fig. 2c). On the other hand, granite G10, belonging to Group III, shows textural features that suggest a faint overprint by $\mathrm{D}_{3}$ during its emplacement, intimately associated to NNE-SSW fault zones, affected by N60-70 ${ }^{\circ} \mathrm{W}$ and N40-50 ${ }^{\circ} \mathrm{E}$ secondary joints (Sousa, 2000), and by strong brittle deformation (Teixeira, 2008; Fig. 1). However, locally there is evidence of a NW-SE magmatic foliation concordant with the regional structure of host metasediments and defined by the orientation of feldspar phenocrysts and, sometimes, biotite. Thus, the geometry and localization of the 
151 different G10 granitic bodies (Fig. 1b) suggest that they were the youngest granite type of the region. The magmatic contacts between granites G8 (and G9) and granite G7 are always sharp, and, locally, the latter phase can occur in the form of rounded enclaves in granites G8 (Fig. 2d) and G9. There are no visible geological contacts between G8, G9 and G10. The geological contacts between granite G10 and G7, and to a lesser extent G9, are always defined by NNE-SSW faults (Fig. 1b).

According to the nomenclature of Didier and Barbarin (1991), granites G7, G8 and G9 contain surmicaceous enclaves, metasedimentary xenoliths and "schlieren" (Fig. 2b), and rare microgranular enclaves. In granite G8 there are irregular to rounded tonalitic enclaves that exhibit sharp contacts with the host granite (Fig. 2e), whereas granite G9 contains monzogranite enclaves that should correspond to fragments of early cold margins removed during magma ascent (Fig. 2f). The monzogranite enclaves partially enclose phenocrysts of the host granite G9 (Fig. 2f). Granite G10 does not contain enclaves.

\section{Petrography}

The most widespread rock type of Group II, G7, as well as G8 and G9, is monzogranite, whereas G10 of Group III is alkali feldspar granite since its plagioclase has less than 5\% anorthite content (Le Maitre et al., 2002). These granites have a subhedral granular texture and contain microcline phenocrysts. Plagioclase phenocrysts are only observed in granite G8. They contain quartz, plagioclase, microperthitic microcline, biotite, some chlorite, muscovite, zircon, apatite, monazite, ilmenite, rutile and anatase (Table 1). Granites G7, G9 and G10 also have tourmaline, whereas sillimanite only occurs in granites G7, G8 and G9. Granite G8 has equal amounts of biotite and muscovite, G7, G9 and G10 are muscovite-dominant granites (Table 1).

Quartz is anhedral and contains inclusions of other minerals (e.g. acicular apatite, rutile, zircon and muscovite). In G10, quartz shows undulatory extinction and is intensely fractured (Fig. $2 \mathrm{~g}$ ).

Microcline is subhedral to anhedral in the matrix, but also forms subhedral microperthitic phenocrysts in all granites. It is cross-hatched twinned and contains inclusions of globular quartz, plagioclase, biotite, muscovite, zircon and apatite. Plagioclase is subhedral to anhedral and polysynthetically twinned. In general, the plagioclase grain boundaries are corroded by microcline, muscovite and quartz (Fig. 2g). Their fractures are filled by muscovite and quartz (Fig. 2g). Plagioclase phenocrysts only occur in G8 and have a composition of albite-oligoclase. Matrix plagioclase is albite- 
oligoclase in G7, G8 and G9 and albite in G10. Myrmekite occurs locally, while intensely fractured feldspars (Fig. 2g) and brecciated aggregates of plagioclase and microcline typically occur in G10.

Biotite and muscovite are commonly subhedral and intergrown, showing textures similar to those of primary muscovites of Miller et al. (1981) and Monier et al. (1984). However, some biotite grains are anhedral and corroded by feldspar and quartz. In the most deformed samples of G10, the micas show undulatory extinction, deformed cleavage planes and even some fracturing (Fig. 2h). Biotite is strongly pleochroic from $\beta$ - and $\gamma$ - reddish brown to $\alpha$ - yellow. Both micas have inclusions of zircon, monazite, apatite (Fig. 2i) and ilmenite. Muscovite has rare inclusions of sillimanite.

Tourmaline is anhedral to subhedral and generally occurs as randomly or concentrically zoned crystals. It partially replaces plagioclase and micas, and usually contains inclusions of quartz, micas, feldspars, zircon and monazite. Tourmaline shows some fracturing, usually filled by quartz.

Zircon and monazite are euhedral and occur mainly included in biotite, muscovite and apatite (Fig. 2i), and locally in feldspars, quartz and tourmaline. Sillimanite occurs as needles in muscovite of G7, G8 and G9. Apatite is the most abundant accessory mineral (Fig. 2i), occurring included in micas, quartz and feldspars. Euhedral to subhedral ilmenite is included mainly in micas, zircon and apatite (Fig. 2i), whereas euhedral rutile is associated to ilmenite and monazite. Secondary muscovite replaces mainly plagioclase and biotite. Rare, secondary titanite and needle-shaped crystals of rutile are associated to minor chloritization of biotite.

\section{Analytical methods}

Samples were crushed in a jaw crusher and grinded in an agate mill. Major and trace elements were determined by X-ray fluorescence analysis at the National Oceanography Centre, University of Southampton, UK, using a Philips MagiX Pro PW 2540 wavelength dispersive XRF spectrometer fitted with a 4 kW Rh target X-ray tube and a VRC Sample Charger (Croudace and Thorpe, 1988; Croudace and Gilligan, 1990). Relative precision is $\pm 1 \%$ for major elements and $\pm 5 \%$ for trace elements.

The determination of whole rock $\mathrm{FeO}$ was carried out by titration with standardised potassium permanganate solution, whereas $\mathrm{H}_{2} \mathrm{O}+$ was determined with a Penfield tube, and $\mathrm{Li}$ by atomic absorption in the Laboratory of Chemistry of the University of Trás-os-Montes e Alto Douro, Vila Real, Portugal. The precision is $\pm 1 \%$ for $\mathrm{FeO}$ and $\mathrm{H}_{2} \mathrm{O}+$ and $\pm 2 \%$ for $\mathrm{Li}$. Fluorine was determined by selective ion 
electrode analysis, with a precision of about 2\%, at the SGS Laboratory, Canada (protocol ISE07A).

The REE ${ }^{\ddagger}$ were determined by ICP-MS, with a precision of about $5 \%$, at the SGS Laboratory, Toronto, Canada, following the protocol IMS95R.

Mineral analyses have been determined on an automated wavelength dispersive electron microprobe (Cameca Camebax SX-100) at the Scientific-Technical Services of the Department of Geology of University of Oviedo, Spain. The analyses were carried out with an accelerating voltage of 15 $\mathrm{kV}$ and a beam current of $15 \mathrm{nA}$. The precision is better than $\pm 2 \%$ and the detection limits were generally $>0.02 \%$ for most elements.

Trace element analyses of minerals were carried out on a VG Elemental Plasmaquad PQ2+ ICPMS coupled to an ArF Excimer 4D Engineering laser system at the National Oceanography Centre, University of Southampton, UK (Gioncada et al., 2005). Measurements were performed using a $20 \mu \mathrm{m}$ laser beam focused on polished $250 \mu \mathrm{m}$ thick sections. Following a pre-ablation period of $10 \mathrm{~s}$, data were collected for $30 \mathrm{~s}$. After collection, the data were corrected for instrumental drift and gas blank, and calibrated against the NIST 610 glass standard, where ten repeated measurements were reproducible to \pm $7 \%$. The detection limits were of 0.1 to $0.5 \mathrm{ppm}$.

The $\mathrm{Sr}$ and $\mathrm{Nd}$ isotope analyses were obtained at the Geochronology and Isotope GeochemistrySGIker Facility of the Universidad del País Vasco UPV/EHU (Spain). Samples $(0.050-0.200 \mathrm{~g})$ were digested with $\mathrm{HNO}_{3}+\mathrm{HF}$ in PFA vials (Savillex) and in HF in high pressure PTFE bombs, employing the method of Pin and Santos Zaldegui (1997). The isotope ratios were then determined by thermal ionization mass spectrometry with a Finnigan MAT 262. Normalization values were ${ }^{86} \mathrm{Sr} /{ }^{88} \mathrm{Sr}=0.1194$ (Steiger and Jäger, 1977) and ${ }^{146} \mathrm{Nd} /{ }^{144} \mathrm{Nd}=0.7219$ (Wasserburg et al., 1981). The values determined for the standards are ${ }^{86} \mathrm{Sr} /{ }^{86} \mathrm{Sr}=0.710273 \pm 0.000018(2 \sigma)$ for NBS 987, and ${ }^{143} \mathrm{Nd} /{ }^{144} \mathrm{Nd}=0.511851 \pm$ $0.000045(2 \sigma)$ for La Jolla. The ratios of ${ }^{87} \mathrm{Rb} /{ }^{86} \mathrm{Sr}$ were calculated from the concentrations of $\mathrm{Rb}$ and $\mathrm{Sr}$ determined by wavelength dispersive XRF, whereas the ratios of ${ }^{147} \mathrm{Sm} /{ }^{144} \mathrm{Nd}$ were calculated from the aforementioned ICP-MS data. Precision is $\pm 1 \%$ for $\mathrm{Rb}$ and $\pm 5 \%$ for $\mathrm{Sr}, \mathrm{Sm}$ and $\mathrm{Nd}$.

Oxygen isotopic data of whole rock samples were determined by gas mass spectrometry. The gas extraction was carried out at the Department of Earth Sciences, University of Western Ontario, Canada,

\footnotetext{
\$ Main abbreviations used in this article: ICP-MS= Inductively Coupled Plasma Mass Spectrometry; L/M/H REE = Light / Middle / Heavy Rare Earth Elements; ID-TIMS = Isotope Dilution - Thermal Ionization Mass Spectrometry; XRF = X-Ray Fluorescence; MSWD = Mean Sum of Weighted Deviations.
} 
236 employing chlorine trifluoride as the reagent (Clayton and Mayeda, 1963). A quartz standard was used

237 and the precision was $\pm 0.2 \%$.

238 Zircon and monazite were concentrated by a combination of magnetic and heavy liquids separation procedures. Grains were subsequently selected by handpicking under a binocular microscope, and mechanically air abraded in order to remove external disturbed domains (Davis et al., 1982; Krogh, 1982). The U-Pb isotopic data for those minerals were obtained by ID-TIMS using a Finnigan MAT 262, at the Department of Geosciences, University of Oslo, Norway, following the standard methodology of Krogh (1973) with the adaptations described by Corfu and Evins (2002) and Corfu (2004). The decay constants are those from Jaffey et al. (1971) and the initial Pb correction was done using the compositions calculated with the Stacey and Kramers (1975) model. The Isoplot program (Ludwig, 1999) was used for plots and regressions. All uncertainties of analyses are given at the $2 \sigma$ level. Monazite mounting and their backscattered electron (BSE) imaging were carried out on the same electron microprobe of University of Oviedo, Spain.

\section{Whole rock geochemistry}

The major and trace element contents of granites G7 to G10 are given in Table 2. The aluminumsaturation index $[\mathrm{Al} /(2(\mathrm{Ca}-1.67 \mathrm{P})+\mathrm{Na}+\mathrm{K})]$ from 1.22 to 1.39 , and normative corundum range from 2.79 to $4.39 \%$, show that all granites are peraluminous. Plotted in the diagrams of Frost and Frost (2008), these granites are magnesian and mainly belong to the alkali-calcic series.

Selected major and trace elements plotted against total $\mathrm{Fe}_{2} \mathrm{O}_{3}$ show two distinct regular trends, mainly defined by curves: a) within the muscovite > biotite granite G7 samples (Fig. 3); b) from the biotite $\approx$ muscovite granite G8, muscovite > biotite granite G9 to muscovite-dominant granite G10 (Fig. $3 \mathrm{a}$ - c and Supplemental electronic Fig. 1). Total $\mathrm{Fe}_{2} \mathrm{O}_{3}$ has been chosen as differentiation index because it shows more variability than $\mathrm{SiO}_{2}$.

The REE contents are low to moderate $(64-287 \mathrm{ppm})$ and chondrite-normalized REE patterns are subparallel within the magmatic series G8 - G9 - G10 (Supplemental electronic data Table 1 and Fig. 4). From G8 to G9 and G10 there is a decrease in the $\Sigma$ REE and in the enrichment in LREE with respect to HREE. The negative Eu anomaly also slightly increases from G8 to G9. The REE pattern of G7 follows a similar trend but it is characterized by a lower $\mathrm{La}_{N} / \mathrm{Lu}_{\mathrm{N}}$ average value (21.30) and a higher 
$265 \mathrm{Eu} / \mathrm{Eu}^{*}$ value (0.37) than those from granites G8 (40.79 and 0.29, respectively) and G9 (36.21 and 0.27, respectively) (Supplemental electronic data Table 1).

The ocean-ridge granite-normalized diagram (Fig. 5) shows a general negative slope, with Rb, Th, Ce (except for G10) and Sm positive anomalies, Ba and Hf negative anomalies, and an enrichment in $\mathrm{Rb}$ and $\mathrm{Th}$ relatively to $\mathrm{Nb}$. These features are characteristic of a crust dominant source (Pearce et al. 1984; Harris et al., 1986). The negative Ba and Hf anomalies suggest fractional crystallization of mainly K-feldspar and zircon.

\section{Age and isotopic compositions}

\subsection{ID-TIMS U-Pb results on zircon and monazite}

Granites G7 to G10 have a diversified population of zircons, formed by autocrystic prisms but also by short to equant crystals, which commonly contain visible cores. The autocrystic zircon crystals of granites G7 to G10 are generally transparent, colourless to light brown and consist of euhedral prisms with terminal pyramid faces. These prisms can reach aspect ratios of up to $>6: 1$, and commonly have melt inclusions. Monazite is euhedral to subhedral.

In granite G7, the two monazite analyses are reversely discordant (Fig. 6a), which is a common feature in this mineral due to the incorporation of significant amounts of ${ }^{230}$ Th during its crystallization that leads to an excess of ${ }^{206} \mathrm{~Pb}$ (Schärer, 1984; Corfu and Evins, 2002). Therefore, the weighted average ${ }^{207} \mathrm{~Pb} /{ }^{235} \mathrm{U}$ age of fractions 6 and 7 of $318 \pm 1 \mathrm{Ma}$ is considered the best indication of the crystallization age of granite G7. The five analysed zircon fractions from this sample are scattered. Two of them are younger than the monazites, probably due to some lead loss (fractions 4 and 5; Table 3 and Fig. 6a). The other three deviate towards older ages likely because of inherited components (fractions 1, 2 and 3; Table 3 and Fig. 6a).

Zircon fractions 10 and 11 from granite G8 yield a concordia age of $316.2 \pm 0.8 \mathrm{Ma}$ (MSWD = 1.5), whereas the only concordant monazite fraction 12 yields a ${ }^{207} \mathrm{~Pb} /{ }^{235} \mathrm{U}$ age of $317.4 \pm 0.7 \mathrm{Ma}$ (Table 3 and Fig. 6b). The combined age of $316.8 \pm 1.3 \mathrm{Ma}$ is considered the best indication for the crystallization age of this granite. The remaining zircon fractions are discordant, showing lead loss (fraction 9; Fig. 6c) and an inherited component (fraction 8; Fig. 6c). A large amount of common lead in the monazite fraction 13 (25 ppm; Table 3) significantly decreased the precision of the ${ }^{207} \mathrm{~Pb} /{ }^{235} \mathrm{U}$ age $(309.0 \pm 7.9 \mathrm{Ma})$, which, 
294 however, still overlaps the combined zircon-monazite age. The monazite fraction 14 is reversely discordant yielding an older ${ }^{207} \mathrm{~Pb} /{ }^{235} \mathrm{U}$ age of $334.4 \pm 1.9 \mathrm{Ma}$, which could either be caused by uranium loss due to an alteration process (Poitrasson et al., 1996; Corfu and Evins, 2002), as evidenced in Fig. 6d, or eventually to the presence of an inherited component.

Four multi-grain monazite analyses for granite G9 (fractions 19-22) show some dispersion (Table 3 and Fig. 6e), which is most probably explained by the presence of inherited components, as suggested by the BSE imaging of this mineral (Fig. 6f). Thus, the weighted average of ${ }^{207} \mathrm{~Pb} /{ }^{235} \mathrm{U}$ ages of the two youngest fractions ( 20 and 21 ) is considered the best estimate for the crystallization of granite G9 $(316.6 \pm 0.5 \mathrm{Ma})$. The four analysed zircon fractions are discordant, as they have inherited components. Among the four analysed monazite fractions for granite G10, three are nearly concordant but show some dispersion in their ${ }^{207} \mathrm{~Pb} /{ }^{235} \mathrm{U}$ ages (Table 3 and Fig. $6 \mathrm{~g}$ ). The BSE imaging also supports the existence of inherited components in some monazites of this granite, reason why the ${ }^{207} \mathrm{~Pb} /{ }^{235} \mathrm{U}$ age of the youngest fraction (29) is considered the most likely age of crystallization of granite G10 (316.2 \pm 0.7

Ma). The remaining monazite fraction (28) is reversely discordant at an older ${ }^{207} \mathrm{~Pb} /{ }^{235} \mathrm{U}$ age $(341.1 \pm 0.8$ Ma). In the granite G10 none of the four zircon fractions is concordant (Fig. 6h), having been affected by lead loss (fractions 23 and 24; Table 3 and Fig. 6h) or by the presence of inherited components (fractions 25 and 26; Table 3 and Fig. 6h).

\subsection{Whole rock $\mathrm{Rb}-\mathrm{Sr}, \mathrm{Sm}-\mathrm{Nd}$ and oxygen isotope data}

The $\mathrm{Rb}, \mathrm{Sr}, \mathrm{Sm}$ and Nd isotopic compositions of eleven whole rock samples were analysed (Supplemental electronic data Table 2). The initial values calculated for an age of 317 Ma plot within a restricted domain from $\left({ }^{87} \mathrm{Sr} /{ }^{86} \mathrm{Sr}\right)_{\mathrm{i}}=0.7133$ for $\mathrm{G} 10$ to 0.7161 for $\mathrm{G} 7$ and $\varepsilon \mathrm{Nd}_{\mathrm{t}}=-9.0$ to -7.6 for $\mathrm{G} 9$ (Fig. 7). Granitic rocks from the Carrazeda de Ansiães area partially match the isotopic composition of the Douro Group (Teixeira et al., 2012a) and northern CIZ metasediments (Villaseca et al., 1998, 2008, 2014), although the hosting metasediments from the Douro Group tend to have somewhat more radiogenic Sr and less radiogenic Nd values, ranging from 0.7128 to 0.7188 and from -10.9 to -8.4 , respectively (Fig. 7). Granites G7 to G10 also plot near the isotopic fields established by Villaseca et al. (1999) for lower crust felsic granulites and orthogneisses from the Spanish Central System. The mean 
$322 \mathrm{~T}_{\mathrm{DM}}$ ages range from $1.28 \mathrm{Ga}$ to $1.86 \mathrm{Ga}$ (Supplemental electronic data Table 2), which are typical values for Variscan granites (e.g. Liew and Hofmann, 1988; Dias et al., 2002).

Three samples of G8, three samples of G9 and two samples of G10 define a Rb-Sr whole rock isochron yielding an age of $315.5 \pm 5.4 \mathrm{Ma}$ and $\left({ }^{87} \mathrm{Sr} /{ }^{86} \mathrm{Sr}\right)_{\mathrm{i}}=0.7155 \pm 0.0010(\mathrm{MSWD}=1.3$; Fig. 8). This $\mathrm{Rb}-\mathrm{Sr}$ age overlaps the more precise ages obtained by $\mathrm{U}-\mathrm{Pb}$ in zircon and monazite.

The mean oxygen isotopic compositions of eight representative samples of granites G7 to G10 range from 10.93 to $11.49 \%$ (Supplemental electronic data Table 2). Such high $\delta^{18} \mathrm{O}$ values are typical of Variscan granitic rocks in Europe (e.g. Hoefs and Emmermann, 1983; Neiva and Gomes, 2001), which have been explained by anatexis of metasedimentary sources (Hoefs, 2009).

\section{Geochemistry of minerals}

\subsection{Feldspars}

The compositions of microcline and plagioclase are given in Supplemental electronic data Table

3. The orthoclase contents in phenocryst and matrix microcline of granites G7 to G10 are similar (89 to 98 mol \%; Supplemental electronic data Table 3), but the $\mathrm{BaO}$ content decreases from phenocryst to matrix in all studied granites, suggesting a magmatic origin of this mineral (e.g. Nekvasil, 1992). The $\mathrm{BaO}$ content in phenocryst microcline is identical in granites $\mathrm{G} 7$ and $\mathrm{G} 8$ and is higher in the matrix of G8 than in that of G7. Furthermore, the $\mathrm{BaO}$ content of microcline decreases from G8 to G9 and G10 (Supplemental electronic data Table 3). Some trace elements of matrix microcline plotted versus whole rock total $\mathrm{Fe}_{2} \mathrm{O}_{3}$ define a trend from G8 to G10 (Supplemental electronic data Table 3 and Supplemental electronic Fig. 2a). The data for microcline from G7 plot outside this trend (Supplemental electronic Fig. 2a).

Plagioclase from granites G7 to G10 is normally zoned, with the anorthite content decreasing from core to rim, and from phenocryst to matrix in G8. The anorthite content of matrix plagioclase from G8 is higher than that from G7, and decreases from G8 to G9 and G10 (Supplemental electronic data Table 3). Some major and trace elements of matrix plagioclase, plotted versus whole rock total $\mathrm{Fe}_{2} \mathrm{O}_{3}$, define curvilinear trends from G8 to G9 and G10 (Supplemental electronic data Table 3 and Supplemental electronic Fig. 2b). The data for plagioclase from G7 do not fit these trends (Supplemental electronic Fig. 2b). 
Although the $\mathrm{P}_{2} \mathrm{O}_{5}$ content of both feldspars is $\leq 0.58 \mathrm{wt} . \%$ in granites $\mathrm{G} 7$ to $\mathrm{G} 10$ (Supplemental electronic data Table 3), there is a general increase in $\mathrm{P}_{2} \mathrm{O}_{5}$ from microcline and plagioclase of G8 to those of G9 and G10 (Supplemental electronic data Table 3). The microcline contains more $\mathrm{P}_{2} \mathrm{O}_{5}$ than coexisting plagioclase, which is in accordance with findings by London et al. (1990), Neiva (1998) and Antunes et al. (2008). The empirical distribution coefficient D[P]Kf/Pl between K-feldspar and plagioclase ranges from 1.38 and 3.00. This coefficient should be about 1.2 in natural feldspars, close to their orthoclase and albite end members, when in equilibrium (London et al., 1999). Granite G10 has $\mathrm{D}[\mathrm{P}] \mathrm{Kf} / \mathrm{Pl}=3.00$ indicating that its microcline started to crystallize before albite or, eventually, that albite was formed from a magma already depleted in phosphorous.

\subsection{Micas}

The average compositions of biotite and muscovite are given in Supplemental electronic data Table 4. Biotites have $\mathrm{Mg} /\left(\mathrm{Mg}+\mathrm{Fe}^{2+}+\mathrm{Fe}^{3+}\right)$ ranging from $0.16-0.36$ (Rieder et al., 1999) and compositions similar to those found in biotites from aluminium-potassic rock series of the biotite \pm cordierite and biotite \pm muscovite fields (Nachit et al., 1985). The biotites from G8 - G10 define fractionation trends for major and trace elements. In general, the data for biotite from $\mathrm{G} 7$ do not fit those trends (Supplemental electronic Fig. 3a).

Muscovites from $\mathrm{G} 7$ to $\mathrm{G} 10$ have high $\mathrm{TiO}_{2}$ and $\mathrm{Al}_{2} \mathrm{O}_{3}$ and low $\mathrm{MgO}$ contents (Supplemental electronic data Table 4) and so are magmatic (Miller et al., 1981; Monier et al., 1984). Variation diagrams for major and trace elements of muscovite versus whole rock total $\mathrm{Fe}_{2} \mathrm{O}_{3}$ show a trend from $\mathrm{G} 8$ to $\mathrm{G} 10$ but do not include G7 (Supplemental electronic Fig. 3b).

\subsection{Ilmenite}

Ilmenite occurs in all granites and its mean Mn content ranges from 0.137 and 0.274 pfu (Supplemental electronic data Table 5). Negative correlations were found between $\mathrm{Mn}$ and $\mathrm{Fe}^{2+}$, and between $\mathrm{Ti}$ and $\mathrm{Fe}^{2+}+\mathrm{Fe}^{3+}+\mathrm{Mn}$ of ilmenite from granites G7 to G10. $\mathrm{Mn}$ and $\mathrm{Mn} /\left(\mathrm{Mn}+\mathrm{Fe}^{2+}\right)$ increase and $\mathrm{Fe}^{2+}$ decreases from the ilmenite of G8 to the ilmenite of G9 and G10 (Supplemental electronic Fig. $3 c)$. 


\section{Regional correlation}

The majority of granitic rocks from the Central Iberian Zone were emplaced at upper and middle crustal levels during the deformation phase $\left(\mathrm{D}_{3}\right)$, following the crustal thickening and subsequent extension related to the Variscan continent-continent collision (Gutiérrez-Alonso et al., 2018). Therefore, the granitic rocks from northern and central Portugal have been classified according to their relation with the aforementioned deformation phase as: syn-orogenic pre- $\mathrm{D}_{3}$, syn- $\mathrm{D}_{3}(\sim 320-310 \mathrm{Ma})$ and late- $\mathrm{D}_{3}(310$ - $300 \mathrm{Ma}$ ), and late- to post orogenic (post-D ${ }_{3}$ ) ( 296 - 290 Ma) (Dias et al., 1998; Ferreira et al., 1987; Valle Aguado et al., 2005). The U-Pb geochronological data for the studied granites, together with the geological field relations, may be interpreted as reflecting two generations of syn- $\mathrm{D}_{3}$ granites: 1 ) the oldest is granite G7 formed at $318 \pm 1 \mathrm{Ma}$; 2) the youngest, formed in the interval of $316.8 \pm 1.3 \mathrm{Ma}$ and $316.2 \pm 0.7 \mathrm{Ma}$, includes granites G8 to G10. The compositions of these granites project in the field of syn-collision granites in the $\mathrm{R}_{1}-\mathrm{R}_{2}$ diagram (La Roche et al., 1980; Batchelor and Bowden, 1985) and also in the tectonic discrimination diagrams of Pearce et al. (1984).

\section{Petrogenesis}

\subsection{Anatectic granitic rocks and their protoliths}

Major and trace elements variations suggest that the muscovite > biotite granite G7 and the biotite $\approx$ muscovite granite G8 formed during distinct magmatic pulses (Fig. 3a - c). Evidence includes the REE patterns, with a distinct enrichment in the LREE (Fig. 4), trace and major elements in microcline (Supplemental electronic Fig. 2a), plagioclase (Supplemental electronic Fig. 2b), biotite (Supplemental electronic Fig. 3a) and muscovite (Supplemental electronic Fig. 3b), but also the existence of intrusive and sharp contacts between granites G8 (and G9) and the granite G7, whereas those between granite G10 and G7 and, to a lesser extent, G9, are always associated to NNE-SSW faults. There are no visible intrusive contacts between G8, G9 and G10 (Fig. 1).

Granites G7 and G8 are peraluminous, with ASI ranging from 1.22 to 1.39 (Table 1), and hence contain aluminum-rich minerals such as biotite, muscovite and sillimanite. These granites also have ilmenite, $\mathrm{K}_{2} \mathrm{O}>\mathrm{Na}_{2} \mathrm{O}$, low $\mathrm{CaO} / \mathrm{Na}_{2} \mathrm{O}$, an enrichment in LREE relative to HREE, negative Eu anomalies, $\left({ }^{87} \mathrm{Sr}{ }^{86} \mathrm{Sr}\right)_{\mathrm{i}}=0.7136$ to $0.7160, \varepsilon \mathrm{Nd}_{\mathrm{t}}=-9.0$ to -7.6 and $\delta^{18} \mathrm{O}=10.93$ to $11.49 \%$ (Supplemental electronic data Table 2), highlighting their affinity to S-type magmas (Chappell and White, 1992). Taking 
409 into account that metapelitic rocks have $\mathrm{CaO} / \mathrm{Na}_{2} \mathrm{O}<0.5$, in contrast to metagreywacke or meta-igneous

410 rocks with $\mathrm{CaO} / \mathrm{Na}_{2} \mathrm{O}=0.3-1.5$, Jung and Pfänder (2007) used this ratio to infer the source composition

411 of peraluminous granites. In granites $\mathrm{G} 7$ and $\mathrm{G} 8$ the $\mathrm{CaO} / \mathrm{Na}_{2} \mathrm{O}$ ratios are 0.18 and 0.27 , respectively,

412 which supports an origin from a mainly metapelitic source. Furthermore, the similarity in the mean

$413 \quad\left({ }^{87} \mathrm{Sr} /{ }^{86} \mathrm{Sr}\right)_{\mathrm{i}}$ and $\varepsilon \mathrm{Nd}_{\mathrm{t}}$ values of granites $\mathrm{G} 7$ and $\mathrm{G} 8$ also indicate that these magmas were formed by partial

414 melting of a commom metapelitic source with a composition comparable to those of Douro Group and

415 northern CIZ metasediments (Villaseca et al., 1998, 2008, 2014; Teixeira et al., 2012a). The U-Pb ID-

416 TIMS data allow to infer that granites G7 and G8 contain Neoproterozoic inherited zircon components

417 (cores, most likely) with ages comparable to those of detrital zircons in metasediments of the Douro

418 Group (e.g. Teixeira et al., 2012b, 2013b), thus supporting their involvement in the origin of the granitic

419 magmas. A fairly identical model involving the partial melting of Neoproterozoic to lower Palaeozoic supracrustal rocks has also been proposed to explain the origin the Variscan granites in the Eastern

421 Erzgebirge / Krušné hory, Central Europe (e.g. Förster and Romer, 2010; Romer et al., 2011; Breiter, 2012). However, it should be reminded that the isotopic composition of granitic magmas derived from a source at depth does not necessarily have a one-to-one relationship, particularly concerning $\mathrm{Sr}$, to the equivalent metamorphic rocks at the level of granitic emplacement. In fact, Miller et al. (1992) and Villaseca et al. (1999) argue that, in orogenic areas, granite sources are not the outcropping metamorphic rocks, but those located at deeper crustal levels.

Although the geochemical and isotopic signatures of granites G7 and G8 indicate a major role of a supracrustal protolith in the genesis of these magmas, the granite G8 of Carrazeda de Ansiães area also contains some tonalitic enclaves, which may point to a local interaction between felsic crustal melts and mafic to intermediate mantle-derived magmas, enough to generate somewhat more primitive isotopic signatures, as for instance in sample GQV9 of granite G8. This mechanism has also been invoked to explain the origin of Variscan granitic intrusions elsewhere in the Central Iberian Zone (e.g. Costa et al., 435 Peninsula pluton, South Africa (Garcia-Arias and Stevens, 2017). 2014; Gomes et al., 2014) and in the French Massif Central (e.g. Williamson et al., 1996; Ledru et al., 2001), as well as to explain the whole range of compositions and geochemical trends of granites of the \\ 437 9.2. Sequential partial melting of $G 7$ and $G 8$}


439 is an increase in $\mathrm{Zr}$, Th, $\mathrm{TiO}_{2}, \mathrm{MgO}, \mathrm{CaO}, \mathrm{V}, \mathrm{Ni}, \mathrm{Sr}$ and $\mathrm{Ba}$ with increasing $\mathrm{Fe}_{2} \mathrm{O}_{3 \mathrm{t}}(\mathrm{Fig}$. 3b - j), indicating

440 that granite G8 could result from a higher degree of partial melting than granite G7 (Holtz and Barbey,

441 1991). Furthermore, granite G7 shows geochemical trends in the variation diagrams (Fig. 3) that seem to

442 continue into G8, suggesting a relation between both granites. However, a fractional crystallization

443 process is not adequate to explain their genesis because G7 is the most evolved and was emplaced up to

$4441 \mathrm{Ma}$ earlier than granite G8. These two granites have identical $\mathrm{Rb},\left({ }^{87} \mathrm{Sr} /{ }^{86} \mathrm{Sr}\right)_{\mathrm{i}}, \varepsilon \mathrm{Nd} \mathrm{t}_{\mathrm{t}}$ and $\delta^{18} \mathrm{O}$ values and 445 subparallel REE patterns, but granite G8 is richer in $\Sigma$ REE and has higher $\mathrm{La}_{\mathrm{N}} / \mathrm{Lu}_{\mathrm{N}}$ average values than

446 G7 (Fig. 4). Both granites also contain surmicaceous enclaves but these are much more abundant in

447 granite G8, which is compatible with a higher degree of partial melting (Holtz and Barbey, 1991;

448 Teixeira, 2008).

449 An estimate of the temperature of formation of unfractionated granitic magmas can be obtained 450 from the $\mathrm{Al}_{2} \mathrm{O}_{3} / \mathrm{TiO}_{2}$ ratio, since magmas with low ratios are generated at higher temperatures than those 451 with high $\mathrm{Al}_{2} \mathrm{O}_{3} / \mathrm{TiO}_{2}$ ratios (Sylvester, 1998; Jung and Pfänder, 2007). On this basis, granite G8

$452\left(\mathrm{Al}_{2} \mathrm{O}_{3} / \mathrm{TiO}_{2}=34.74\right)$ originated at a higher temperature than $\mathrm{G} 7\left(\mathrm{Al}_{2} \mathrm{O}_{3} / \mathrm{TiO}_{2}=72.53\right)$. The conditions of 453 formation of granitic magmas can also be obtained from the zircon saturation equation (Watson and 454 Harrison, 1983), assuming equilibrium conditions. The average zircon saturation temperature (Tzr) is of $455816^{\circ} \mathrm{C}$ for $\mathrm{G} 8$ and $734{ }^{\circ} \mathrm{C}$ for $\mathrm{G} 7$, which indicates a higher degree of partial melting for G8 (Miller et al., 456 2003). However, these Tzr values are overestimated since there are inherited zircon cores in both granites 457 (Watson and Harrison, 1983).

459 (Supplemental electronic data Table 3), while anorthite content of matrix plagioclase from G8 is higher 460 than that from G7 (Supplemental electronic data Table 3). Both phenocryst- and matrix- feldspars from 461 G8 have less $\mathrm{P}_{2} \mathrm{O}_{5}$ than those in $\mathrm{G} 7$ (Supplemental electronic data Table 3). Biotite and muscovite from $462 \mathrm{G} 8$ have more $\mathrm{MgO}$ and less Li than those from G7 (Supplemental electronic data Table 4), whereas muscovite from G7 is richer in F than that from G8 (Supplemental electronic data Table 4). Therefore, the they are not related by a fractional crystallization mechanism. 
The apparently sequential partial melting evolution from muscovite > biotite granite G7 (318 \pm 1

$467 \mathrm{Ma})$ to biotite muscovite granite G8 (316.8 $\pm 1.3 \mathrm{Ma})$ from Carrazeda de Ansiães area is comparable to

468 that observed for other Portuguese Variscan granites, namely those from the Tourém area (Holtz and

469 Barbey, 1991; Neiva, 1994), the Guarda-Sabugal area (Neiva et al., 2011a) and the Penafiel area

470 (Carvalho et al., 2012), and also in other areas elsewhere, e.g. those in the Achiras complex, Córdoba,

471 Argentina (Otamendi et al., 1998).

472 The generation of granitic rocks from the same source by sequential partial melting is a rare

473 process, whose occurrence in Portugal is mainly explained by the combination of an intense crustal

474 thickening during the Variscan orogeny that established a high geothermal gradient, and the subsequent collapse, extension and mantle upwelling (Clemens, 2003; Valle Aguado et al., 2005; Gutiérrez-Alonso et al., 2018). At Carrazeda de Ansiães area, this is also supported by the presence of scarce tonalitic enclaves in granite G8, formed at higher temperatures, and their absence in granite G7.

\subsection{Series of fractional crystallization}

Granites G8, G9 and G10, with identical crystallization ages, at $316.8 \pm 1.3 \mathrm{Ma}, 316.6 \pm 0.5 \mathrm{Ma}$ and 316.2 $\pm 0.7 \mathrm{Ma}$, respectively, but with no visible intrusive contacts, seem to define a magmatic differentiation series as they define curvilinear trends in major and trace elements diagrams (Fig. 3a - c and Supplemental electronic Fig. 1), and show decreasing Ba contents of phenocryst and matrix microcline (Supplemental electronic data Table 3), decreasing anorthite content of plagioclase (Supplemental electronic data Table 3), fractionation trends for microcline (Supplemental electronic Fig. 2a), plagioclase (Supplemental electronic Fig. 2b), biotite (Supplemental electronic Fig. 3a), muscovite (Supplemental electronic Fig. 3b) and ilmenite (Supplemental electronic Fig. 3c), and subparallel whole rock REE patterns within each series (Fig. 4). The decrease in LREE from G8, to G9 and G10 can be explained by fractionation of monazite (Bea, 1996), whereas the decrease in the MREE can be due to apatite fractionation (Henderson, 1984), and the decrease in HREE to zircon fractionation (Yurimoto et al., 1990; Bea, 1996), in agreement with the decrease in Zr from G8 to G9 and G10 (Table 2). The Sr and $\mathrm{Nd}$ isotopic compositions are relatively uniform, although with some differences in G8, G9 and G10 and even within each granite type (Fig. 7). There is no significant variation in $\delta^{18} \mathrm{O}$ values, which also supports a fractional crystallization mechanism. The slightly decrease in the $\delta^{18} \mathrm{O}$ value of granite G10 
495 can be attributed to some oxygen-isotope exchange at subsolidus temperature between feldspar and quartz

496 (Blattner et al., 2002). Furthermore, $\left({ }^{87} \mathrm{Sr} /{ }^{86} \mathrm{Sr}\right.$ ) versus $1 / \mathrm{Sr}$ does not define a positive correlation for the

497 series, which would confirm that assimilation or mixing processes did not play a major role.

498 Major and trace element contents were used for testing fractional crystallization. The average of 499 the two least silicic samples of granite G8 was selected as the starting magma, while the average of the 500 two most silicic samples of G8, the average of samples GC8 and GC7 of granite G9 and three samples of 501 G10 (GAJ13, GAJ8 and GAJ11), free of metasomatic effects, were selected as residual liquids. The leastsquares regression method was applied to model major elements using pure anorthite, albite, K-feldspar and quartz compositions together with the compositions of biotite and ilmenite analysed with the electron microprobe in the G8 sample with the lowest $\mathrm{SiO}_{2}$ content. The calculated compositions of parent magma for the granites compare well with the respective determined parent granite and the sum of the squares of the residuals $\Sigma \mathrm{R}^{2}$ is $\leq 0.0115$ (Supplemental electronic data Table 6). The anorthite content of fractionating plagioclase in the cumulate is close to that of the core of plagioclase phenocrysts in the G8 sample with the lowest $\mathrm{SiO}_{2}$. The percentages of quartz and $\mathrm{K}$-feldspar increase and those of plagioclase, biotite and ilmentite decrease in the cumulate versus the decrease in the weight fraction of melt remaining

$514 \mathrm{Rb}$, which are the most informative trace elements for evaluating the fractionation of granitic rocks.

515 Strontium and $\mathrm{Ba}$ decrease and $\mathrm{Rb}$ increases with the decrease in the remaining melt during fractional 516 crystallization from G8 to G9 and G10 (Supplemental electronic data Table 6). The calculated Sr, Ba and

$517 \mathrm{Rb}$ values are consistent with the measured data although the calculated $\mathrm{Sr}$ and $\mathrm{Ba}$ values for G10 are

518 generally higher and the calculated $\mathrm{Rb}, \mathrm{Rb} / \mathrm{Ba}$ and $\mathrm{Rb} / \mathrm{Sr}$ ratios are lower than the measured data

519 (Supplemental electronic data Table 6 and Supplemental electronic Fig. 4). This may be due to uncertainties in the distribution coefficients and the possibility that magmatic fluids might have controlled 521 the behaviour of LIL elements in the most evolved granitic rocks (e.g. Neiva 1998; Antunes et al., 2008; Huang et al., 2014; Xu et al., 2015; Romer and Kroner, 2016; Pan et al., 2018; Roda-Robles et al., 2018; Nguyen et al., 2019). 
The described process is in agreement with the studies done on other European Variscan granitic

plutons where fractional crystallization contributed to an enrichment in lithophile and fluxing elements, namely in granites of the Cornubian batholith, England (Müller et al., 2006; Simons et al., 2016, 2017; Smith et al., 2019), in some granites of Krušné hory / Erzgebirge Mountains, Central Europe (Breiter, 2012), in the highly evolved peraluminous granite of Belvís de Monroy, Spain (Merino Martínez et al., 2014), but also in granitic suites elsewhere, e.g. along the southeastern margin of the North China Craton (Li et al., 2020), in the Mufushan complex, South China (Wang et al., 2014) and in the Lhasa Terrane, southern Tibet (Zhang et al., 2019).

\section{Tin content of granites and its origin}

Among the late syn- $\mathrm{D}_{3}$ granitic suite of Carrazeda de Ansiães (G7 - G10), the only Sn-bearing granites in the sense of Neiva (1984) and Lehmann (1990) are the muscovite > biotite granite G7 and muscovite-dominant granite G10, with mean Sn contents of 20 and $31 \mathrm{ppm}$, respectively (Table 2). The main occurrences of tin- and tungsten-bearing quartz veins are in granite G10, but some are also spatially related with G7.

The role of fractional crystallization in the genesis of tin-mineralized early syn- $\mathrm{D}_{3}$ granites (G1 G6) from Carrazeda de Ansiães area has been previously evidenced by Teixeira et al. (2012a).

Nevertheless, this mechanism is recurrently invoked to explain the occurrence of Sn-bearing granites in similar geological contexts (Neiva, 1984, 2002; Lehmann, 1990; Gomes and Neiva, 2002; Neiva et al., 2011b; Jiang et al., 2015; Ding et al., 2017; Chen et al., 2018; Feng et al., 2018). The absence of cassiterite in the independent magmatic pulse G7 and in granites of the differentiation series G8 - G10 precludes a significant retention of Sn in micas. There is indeed a progressive enrichment in Sn from G8 to G9 and G10, which may be explained by its increase in the hosted biotite and primary muscovite (Fig. 9). This points to a concentration conditioned by a fractional crystallization mechanism, where the low $f \mathrm{O}_{2}$ favours the enrichment of $\mathrm{Sn}$ in residual liquids (Lehmann, 1990; Chicharro et al., 2016; Qiu et al., 2017; Roda-Robles et al., 2018; Cao et al., 2020; Cruz et al., 2020). In the $\log \mathrm{Sn}-\log \mathrm{Rb} / \mathrm{Sr}$ plot (Fig. 10) the correlation line for G8, G9 and G10 follows a Sn enrichment where the fractionation trend is traceable back to below $1 \mathrm{ppm} \mathrm{Sn} \mathrm{in} \mathrm{the} \mathrm{least} \mathrm{evolved} \mathrm{portions,} \mathrm{showing} \mathrm{that} \mathrm{there} \mathrm{was} \mathrm{no} \mathrm{primary} \mathrm{Sn}$ 
552 enrichment (Lehmann, 1990), in agreement with the low Sn values of the host metasedimentary rocks $(<$

5535 ppm; Teixeira et al., 2012a). Therefore these granites do not reflect a crustal anomaly in Sn.

554 Despite the similar to marginally lower Sn contents in primary muscovite, when compared to

555 those in the coexisting biotite (Supplemental electronic data Table 4 and Fig. 9), muscovite would retain

556 more $\mathrm{Sn}$ than biotite due to its higher abundance in the rock (Table 2). In fact, of the total amount of Sn in

557 the whole rock, primary muscovite would retain an average of $15 \%$ in G7, $15 \%$ in G8, $15 \%$ in G9 and

$55818 \%$ in G10, while biotite would hold an average of $14 \%$ in G7, $15 \%$ in G8, $10 \%$ in G9 and $4 \%$ in

559 G10. Therefore, with the increasing degree of differentiation from G7 to G10, the percentage of Sn

560 retained in muscovite tends to increase, while that retained in biotite decreases.

561 The tin-bearing granites from the Central Iberian Zone are the parent rocks of mineralisations

562 that mainly occur in pegmatites and quartz veins (Neiva, 1984; Lehmann, 1990; Almeida et al., 2002;

563 Neiva and Ramos, 2010), although cassiterite may also occur in some aplites (Charoy and Noronha,

564 1996), greisens (Wang et al., 2017) and locally in granites (Gomes and Neiva, 2002). In general, these specialized granites result from the partial melting of metasedimentary rocks, as indicated by $\mathrm{Sr}$ and $\mathrm{Nd}$ isotope data from different areas of Portugal and Spain (Neiva, 2002; Neiva et al., 2009, 2011a; Ruiz et al., 2008), other domains of the Variscan orogenic belt, like the Cornubian batholith, England (Müller et al., 2006) and Erzgebirge, Germany (Romer et al., 2016), and elsewhere, e.g. in the W-Sn polymetallic metallogenic belt at the southeast Yunnan Province in the southwestern Yangtze Block, South China (Liu

\section{Conclusions}

This study in northern Portugal concerns a mesozonal granitic suite intruded into Precambrian to

Ordovician metasedimentary rocks during the syn-kinematic stages of the Variscan orogeny. This multiphase granitic complex evolved as ten intrusive phases as identified from field, geochemical and isotopic data. metasedimentary structures, suggesting that they were affected by the last stages of the third phase of deformation $\left(D_{3}\right)$ of the Variscan orogeny while in the magmatic state. Granite G10 belongs to Group III and is characterized by a strong brittle deformation, probably due to its preferential emplacement in late 
581 NNE-SSW fault zones. The U-Pb ages for zircon and monazite show that these granites are the youngest of the Carrazeda de Ansiães area (318 \pm 1 Ma to $316.2 \pm 0.7 \mathrm{Ma})$.

Granites G7 and G8 are peraluminous and have similar $\left({ }^{87} \mathrm{Sr} /{ }^{86} \mathrm{Sr}\right)_{317}, \varepsilon \mathrm{Nd}_{317}$ and $\delta^{18} \mathrm{O}$ values, but distinct major, trace and rare earth element contents and compositions of feldspars and micas. Granite G8 resulted from a higher degree of partial melting of the same metasedimentary source, probably metapelitic, than granite G7.

Granite G8 magma evolved by fractional crystallization, which is confirmed by the major and trace element trends defined by G8, G9 and G10, the decrease in REE contents from G8 to G10, their similar $\left({ }^{87} \mathrm{Sr} /{ }^{86} \mathrm{Sr}\right)_{\mathrm{i}}, \varepsilon \mathrm{Nd}_{\mathrm{i}}$ and $\delta^{18} \mathrm{O}$ values, but also by the compositions of feldspars and micas. Granites G9 and G10 are derived from granite G8 magma by fractionation of quartz, K-feldspar, plagioclase, biotite and ilmenite.

Fractional crystallization increased the Sn content of magma within the G8-G9-G10 series. Tinbearing granites G7 and G10 do not represent a crustal anomaly of Sn.

The high geothermal gradients due to the middle Carboniferous Variscan continent-continent collision and the subsequent post-thickening extension, probably accompanied by the intrusion of mantlederived magmas in the lower crust, caused partial melting of crustal material.

\section{Acknowledgements}

This paper corresponds to a part of the PhD thesis of R. J. S. Teixeira. We are grateful to Prof. Robert Nesbitt who managed the EU SOCFAC facility (HPRI-1999-CT-00108) that led to access to geochemical facilities at the University of Southampton (United Kingdom), Dr. Andy Milton (at the same institution) for the skilled assistance in the laser ablation ICP-MS laboratory, Prof. José Ignacio Gil Ibarguchi, Dr. Sonia García de Madinabeitia and Dr. Maria Eugenia Sanchez Lorda for the Rb-Sr and Sm-Nd isotopic data obtained at the Geochronology and Isotope Geochemistry- SGIker Facility of the Universidad del País Vasco UPV/EHU (Spain). Prof. Fred J. Longstaffe for the oxygen-isotope analyses obtained at the Department of Earth Sciences, University of Western Ontario (Canada). R. J. S. Teixeira also thanks to Álvaro Miranda, Dr. Alvaro Rubio, Márcio Silva, Miguel Fernández, Nelson Pinto, Simão Botelho and Tito Azevedo for their help in field and laboratory works. Funding was provided to R. J. S. Teixeira by the SFRH/BD/17246/2004 PhD grant from FCT - Fundação para a 
610 Ciência e a Tecnologia, Portugal, and another grant from SOCFAC (Southampton Oceanography Centre,

611 Facilities and Co-Operation). This research was financially supported by the Pole of the Geosciences

612 Centre (CGeo) and projects UIDB/00073/2020 and UIDP/00073/2020 through FCT - Portuguese

613 Foundation for Sciences and Technology. Very helpful constructive reviews and comments were

614 provided by two anonymous referees. We are also grateful to the Guest Editors for the final comments.

615

616

617

618

619

620

621

622

623

624

625

626

627

628

629

630

631

632

633

634

635

636

637

638 


\section{References}

640 Almeida, M. A., Martins, H. C. \& Noronha, F. (2002). Hercynian acid magmatism and related 641 mineralizations in Northern Portugal. Gondwana Research, 5, 423-434.

642 Antunes, I. M. H. R., Neiva, A. M. R., Silva, M. M. V. G., \& Corfu, F. (2008). Geochemistry of S-type granitic rocks from the reversely zoned Castelo Branco pluton (central Portugal). Lithos, 103(3-4), 445-465. https://doi.org/10.1016/j.lithos.2007.10.003

Arth, J. G. (1976). Behaviour of trace elements during magmatic processes - a summary of theoretical models and their applications. Journal of Research of the Unites States Geological Survey, 4, 41-47.

Azevedo, M. R. \& Nolan, J. (1998). Hercynian late-post-tectonic granitic rocks from the Fornos de Algodres area (Northern Central Portugal). Lithos, 44(1-2), 1-20. https://doi.org/10.1016/S00244937(98)00019-X

Azevedo, M. R. \& Valle Aguado, B. (2006). Origem e instalação de granitóides variscos na Zona CentroIbérica. In Dias, R., Araújo, A., Terrinha, P., Kullberg, J. (Eds.), Geologia de Portugal no contexto da Ibéria (pp. 107-121). Évora: Universidade de Évora.

Batchelor, R. A. \& Bowden P. (1985). Petrogenetic interpretation of granitoid rock series using multicationic parameters. Chemical Geology, 48, 43-55.

Bea, F. (1996). Residence of REE, Y, Th and U in granites and crustal protoliths; implications for the chemistry of crustal melts. Journal of Petrology, 37(3), 521-552. https://doi.org/10.1093/petrology/37.3.521

Bea, F., Montero, P. \& Zinger, T. (2003). The Nature and Origin of the Granite Source Layer of Central Iberia: Evidence from Trace Element, $\mathrm{Sr}$ and $\mathrm{Nd}$ Isotopes, and Zircon Age Patterns. Journal of Geology, 111, 579-595.

Beetsma, J. J. (1995). The late Proterozoic/Paleozoic and Hercynian crustal evolution of the Iberian Massif, N Portugal. Unpublished PhD thesis, Vrije Universiteit Amsterdam, 223 p.

Blattner, P., Abart, R., Adams, C. J., Faure, K. \& Hui, L. (2002). Oxygen isotope trends and anomalies in granitoids of the Tibetan plateau. Journal of Asian Earth Sciences, 21(3), 241-250.

Breiter, K. (2012). Nearly contemporaneous evolution of the A- and S-type fractionated granites in the Krušné hory/Erzgebirge Mts., Central Europe. Lithos, 151, 105-121. https://doi.org/https://doi.org/10.1016/j.lithos.2011.09.022 
668 Bruyin, H., Westhuizen, W. A. \& Schoch, A. E. (1983). The estimation of FeO, F, and $\mathrm{H}_{2} \mathrm{O}^{+}$by regression in microprobe analysis of natural biotite. Journal of Trace and Microprobe Techniques, 1, $399-413$.

Cao, J., Wu, Q., Yang, X., Deng, X., Li, H., Kong, H., \& Xi, X. (2020). Geochemical factors revealing the differences between the Xitian and Dengfuxian composite plutons, middle Qin-Hang Belt: Implications to the W-Sn mineralization. Ore Geology Reviews, 118. https://doi.org/10.1016/j.oregeorev.2020.103353

Carvalho, P. C. S., Neiva, A. M. R., Silva, M. M. V. G., \& Corfu, F. (2012). A unique sequential melting mechanism for the generation of anatectic granitic rocks from the Penafiel area, northern Portugal. Lithos, 155, 110-124. https://doi.org/10.1016/j.lithos.2012.08.019

Chappell, B. W., White, A. J. R. (1992). I- and S-type granites in the Lachlan Fold Belt. Transactions of the Royal Society of Edinburgh Earth Sciences, 83, 1-26.

Charoy, B., Noronha, F., 1996. Multistage growth of a rare-element volatile-rich microgranite at Argemela (Portugal), Journal of Petrology, 37, 73-94.

Chen, X., Liang, H., Richards, J. P., Huang, W., Zhang, J., Wu, J., \& Sotiriou, P. (2018). Age and granite association of skarn W mineralization at Niutangjie district, South China Block. Ore Geology Reviews, 102, 268-283. https://doi.org/10.1016/j.oregeorev.2018.09.003

Chicharro, E., Boiron, M. C., López-García, J. Á., Barfod, D. N., \& Villaseca, C. (2016). Origin, ore forming fluid evolution and timing of the Logrosán Sn-(W) ore deposits (Central Iberian Zone, Spain). Ore Geology Reviews, 72, 896-913. https://doi.org/10.1016/j.oregeorev.2015.09.020

Clayton, R. N. \& Mayeda, T. K. (1963). The use of bromine pentafluoride in the extraction of oxygen from oxides and silicates for isotopic analysis. Geochimica et Cosmochimica Acta, 27, 43-52.

Clemens, J. D. (2003). S-type granitic magmas - petrogenetic issues, models and evidence. Earth-Science Reviews, 61, 1-18.

Coke, C. J. M., Teixeira, R. J. S., Gomes, M. E. P., Corfu, F. \& Rubio Ordóñez, A. (2011). Early Ordovician volcanism in Eucísia and Mateus areas, Central Iberian Zone, northern Portugal (Goldschmidt Conference Abstract). Mineralogical Magazine, 75(3), 685.

Corfu, F. \& Evins, P. M. (2002). Late Paleoproterozoic monazite and titanite U-Pb ages in the Archean Suomujärvi complex, N Finland. Precambrian Research, 116, 171-181. 
697 Corfu, F. (2004). U-Pb age, setting and tectonic significance of the anorthosite-mangerite-charnockite-

698 granite suite, Lofoten-Vesterålen, Norway. Journal of Petrology, 56, 2081-2097.

699 Costa, M. M., Neiva, A. M. R., Azevedo, M. R., \& Corfu, F. (2014). Distinct sources for syntectonic 700 Variscan granitoids: Insights from the Aguiar da Beira region, Central Portugal. Lithos, 196-197,

701

702
83-98. https://doi.org/10.1016/j.lithos.2014.02.023

Croudace, I. W. \& Gilligan, J. (1990). Versatile and accurate trace element determinations in iron-rich and other geological samples using X-ray fluorescence analysis. X-ray Spectrometry, 19, 117-123.

Croudace, I. W. \& Thorpe, O. W. (1988). A low dilution, wavelength dispersive X-ray fluorescence procedure for the analysis of archaeological rock artefacts. Archaeometry, 30, 227-236.

Cruz, C., Sant'Ovaia, H., \& Noronha, F. (2020). Magnetic mineralogy of variscan granites from northern Portugal: An approach to their petrogenesis and metallogenic potential. Geologica Acta, 18. https://doi.org/10.1344/GeologicaActa2020.18.5

Davis, D. W., Blackburn, C. E. \& Krogh, T. E. (1982). Zircon U-Pb ages from the Wabigoon. Manitou Lakes Region, Wabigoon Subprovince, northwest Ontario. Canadian Journal of Earth Sciences, 19, 254-266.

De Paolo, D. J. (1981). Trace element and isotopic effects of combined wall rock assimilation and fractional crystallization. Earth and Planetary Science Letters, 53, 189-202.

Dias, G., Leterrier, J., Mendes, A., Simões, P. P., \& Bertrand, J. M. (1998). U-Pb zircon and monazite geochronology of post-collisional Hercynian granitoids from the Central Iberian Zone (Northern Portugal). Lithos, 45(1-4), 349-369. https://doi.org/10.1016/S0024-4937(98)00039-5

Dias, G., Simões, P. P., Ferreira, N. \& Leterrier, J. (2002). Mantle and crustal sources in genesis of lateHercynian granitoids (NW Portugal). Geochemical and Sr-Nd isotopic constraints. Gondwana Research, 5, 287-305.

Dias, R. \& Coke, C. (2006). O funcionamento dos grandes acidentes crustais no controlo da génese e instalação das rochas graníticas na Zona Centro Ibérica. In Dias, R., Araújo, A., Terrinha, P., Kullberg, J. (Eds.), Geologia de Portugal no contexto da Ibéria (pp. 1231-1234). Évora: Universidade de Évora. 
724 Didier, J. \& Barbarin, B. (1991). The different types of enclaves in granites - Nomenclature. In Didier, J.

\& Barbarin, B. (Eds.), Enclaves in Granite Pretrology. Developments in Petrology, vol. 13 (pp. 1923). Amsterdam: Elsevier.

Ding, J., Han, C., Xiao, W., Wang, Z., \& Song, D. (2017). Geochronology, geochemistry and Sr-Nd isotopes of the granitic rocks associated with tungsten deposits in Beishan district, NW China, Central Asian Orogenic Belt: Petrogenesis, metallogenic and tectonic implications. Ore Geology Reviews, 89, 441-462. https://doi.org/10.1016/j.oregeorev.2017.06.018

Feng, C., Wang, H., Xiang, X., \& Zhang, M. (2018). Late Mesozoic granite-related W-Sn mineralization in the northern Jiangxi region, SE China: A review. Journal of Geochemical Exploration, 195, 3148. https://doi.org/10.1016/j.gexplo.2018.06.008

Ferreira, N., Iglésias, M., Noronha, F., Pereira, E., Ribeiro, A. \& Ribeiro, M. L. (1987). Granitóides da zona Centro-Ibérica e seu enquadramento geodinâmico. In Bea, F., Carmina, A., Gonzalo, J.C., Plaza, M.L., Rodrigues, J.M.L. (Eds.), Geologia de los granitoids y rocas associadas del Macizo Hespérico, Libro Homenagem a L.C.G. Figueirola ( pp. 37-53). Madrid: Editorial Rueda.

Förster, H.-J. \& Romer, R. L. (2010). Carboniferous magmatism. In Linnemann, U., Romer, R. L. (Eds.), The pre-Mesozoic Geology of Saxo-Thuringia - From the Cadomian Active Margin to the Variscan Orogen (pp. 287-308). Stuttgart: Schweizerbart Science Publishers.

Frost, B. R., \& Frost, C. D. (2008). A geochemical classification for feldspathic igneous rocks. Journal of Petrology, 49(11), 1955-1969. https://doi.org/10.1093/petrology/egn054

Garcia-Arias, M., \& Stevens, G. (2017). Phase equilibrium modelling of granite magma petrogenesis: B. An evaluation of the magma compositions that result from fractional crystallization. Lithos, 277, 109-130. https://doi.org/10.1016/j.lithos.2016.09.027

Gioncada, A., Mazzuoli, R. \& Milton, A. J. (2005). Magma mixing at Lipari (Aeolian Islands, Italy): Insights from textural and compositional features of phenocrysts. Journal of Volcanology and Geothermal Research, 145, 97-118.

Gomes, M. E. P., \& Neiva, A. M. R. (2002). Petrogenesis of tin-bearing granites from Ervedosa, northern Portugal: The importance of magmatic processes. Chemie Der Erde, 62(1), 47-72. https://doi.org/10.1078/0009-2819-00002 
Gomes, M. E. P., Teixeira, R. J. S., Neiva, A. M. R., \& Corfu, F. (2014). Geoquímica e geocronologia dos granitóides da região de Bemposta-Picote, Nordeste de Portugal. Comunicações Geológicas, 101, 115-118.

Gutiérrez-Alonso, G., Fernández-Suárez, J., López-Carmona, A., \& Gärtner, A. (2018). Exhuming a cold case: The early granodiorites of the northwest Iberian Variscan belt-A Visean magmatic flare-up? Lithosphere, 10(2), 194-216. https://doi.org/10.1130/L706.1

Harris, N. B. W., Pearce J. A. \& Tindle A.G. (1986). Geochemical characteristics of collision zone magmatism. In Coward, M. P. \& Ries A. C. (1986). Collision Tectonics (Special Publication 19, pp. 67-81). London: The Geological Society of London.

Henderson, P. (1984). Chapter 1 - General Geochemical Properties and Abundances of the Rare Earth Elements. In P. B. T.-D. in G. Henderson (Ed.), Rare Earth Element Geochemistry (Vol. 2, pp. 132). Elsevier. https://doi.org/https://doi.org/10.1016/B978-0-444-42148-7.50006-X

Hoefs, J. \& Emmermann, R. (1983). The oxygen isotopic composition of Hercynian granites and preHercynian gneisses from the Schwarzwald, SW Germany. Contributions to Mineralogy and Petrology, 83, 320-329.

Hoefs, J. (2009). Stable Isotope Geochemistry, 6th edition. Berlin Heidelberg: Springer-Verlag,

Holtz, F. \& Barbey, P. (1991). Genesis of peraluminous granites II. Mineralogy and chemistry of the Tourem complex (northern Portugal). Sequential melting vs. restite unmixing. Journal of Petrology 32, 959-978.

Huang, L.-C., \& Jiang, S.-Y. (2014). Highly fractionated S-type granites from the giant Dahutang tungsten deposit in Jiangnan Orogen, Southeast China: Geochronology, petrogenesis and their relationship with W-mineralization. Lithos, 202-203, 207-226. https://doi.org/10.1016/j.lithos.2014.05.030

Jaffey, A. H., Flynn, K. F., Glendenin, L. E., Bentley, W. C., \& Essling, A. M. (1971). Precision measurement of half-lives and specific activities of U235 and U238. Physical Review C, 4(5), 1889-1906. https://doi.org/10.1103/PhysRevC.4.1889

Jiang, S., Peng, N., Huang, L., Xu, Y., Zhan, G., \& Dan, X. (2015). Geological characteristic and ore genesis of the giant tungsten deposits from the Dahutang ore-concentrated district in northern Jiangxi Province. Yanshi Xuebao/Acta Petrologica Sinica, 31(3), 639-655. 
781 Jung, S. \& Pfänder, J. A. (2007). Source composition and melting temperatures of orogenic granitoids: constrains from $\mathrm{CaO} / \mathrm{Na}_{2} \mathrm{O}, \mathrm{Al}_{2} \mathrm{O}_{3} / \mathrm{TiO}_{2}$ and accessory mineral saturation thermometry. European Journal of Mineralogy, 19, 859-870.

Krogh, T. E. (1973). A low contamination method for hydrothermal decomposition of zircon and extraction of $\mathrm{U}$ and $\mathrm{Pb}$ for isotopic age determination. Geochimica et Cosmochimica Acta, 37, 485494.

Krogh, T. E. (1982). Improved accuracy of U-Pb zircon ages by creation of more concordant systems using an air abrasion technique. Geochimica et Cosmochimica Acta, 46, 637-649.

La Roche, H., Letterier, J., Grand Claude, P. \& Marchal, M. (1980). A classification of volcanic and plutonic rocks using $\mathrm{R}_{1}-\mathrm{R}_{2}$ diagrams and major elements analyses - its relationships with current nomenclature. Chemical Geology, 29, 183-210.

Le Maitre, R., Streckeisen, A., Zanettin, B., Le Bas, M., Bonin, B., \& Bateman, P. (Eds.). (2002). Igneous Rocks: A Classification and Glossary of Terms: Recommendations of the International Union of Geological Sciences Subcommission on the Systematics of Igneous Rocks (2 ${ }^{\text {nd }}$ ed.). Cambridge: Cambridge University Press. doi:10.1017/CBO9780511535581

Ledru, P., Courrioux, G., Dallain, C., Lardeaux, J.-M., Montel, J.-M., Vanderhaeghe, O. \& Vitel, G. (2001). The Velay dome (French Massif Central): melt generation and granite emplacement during orogenic evolution. Tectonophysics, 342, 207-227.

Lehmann, B. (1990). Metallogeny of tin. Lecture Notes in Earth Sciences. Berlin: Springer-Verlag.

Li, C., Yan, J., Yang, C., Song, C.-Z., Wang, A.-G., \& Zhang, D.-Y. (2020). Generation of leucogranites via fractional crystallization: A case study of the Jurassic Bengbu granite in the southeastern North China Craton. Lithos, 352-353. https://doi.org/10.1016/j.lithos.2019.105271

Liew, T. C. \& Hofmann, A. W. (1988). Precambrian crustal components, plutonic associations, plate environment of the Hercynian Fold Belt of Central Europe: indications from a Nd and Sr study. Contributions to Mineralogy and Petrology, 98, 129-138.

Liu, Y., Zhang, L., Mo, X., Santosh, M., Dong, G., \& Zhou, H. (2020). The giant tin polymetallic mineralization in southwest China: Integrated geochemical and isotopic constraints and implications for Cretaceous tectonomagmatic event. Geoscience Frontiers. https://doi.org/10.1016/j.gsf.2020.01.007 
810 London, D., Černý, P., Loomis, J. L. \& Pan, J. L. (1990). Phosphorus in alkali feldspars of rare-element 811 granitic pegmatites. American Mineralogist, 28, 771-786.

812 London, D., Wolf, M. B., Morgan VI, G. B., \& Garrido, M. G. (1999). Experimental silicate-phosphate 813 equilibria in peraluminous granitic magmas, with a case study of the Alburquerque batholith at Tres 814 Arroyos, Badajoz, Spain. Journal of Petrology, 40(1), 215-240.

815 https://doi.org/10.1093/petroj/40.1.215

816 Ludwig, K. R. (1999). Isoplot/Ex version 2.03. A geochronological toolkit for Microsoft Excel. Berkeley 817 Geochronology under Special Publication, vol. 1. 43 pp.

818 Martins, H. C. B., Sant'Ovaia, H., \& Noronha, F. (2013). Late-Variscan emplacement and genesis of the 819 Vieira do Minho composite pluton, Central Iberian Zone: Constraints from U-Pb zircon geochronology, AMS data and $\mathrm{Sr}-\mathrm{Nd}-\mathrm{O}$ isotope geochemistry. Lithos, 162-163, 221-235. https://doi.org/https://doi.org/10.1016/j.lithos.2013.01.001

Martins, H. C. B., Sant'Ovaia, H., Noronha, F. (2009). Genesis and emplacement of felsic Variscan plutons within a deep crustal lineation, the Penacova-Régua-Verín fault: An integrated geophysics and geochemical study (NW Iberian Peninsula). Lithos, 111, 142-155.

Merino Martínez, E., Villaseca, C., Orejana, D., Pérez-Soba, C., Belousova, E., \& Andersen, T. (2014). Tracing magma sources of three different S-type peraluminous granitoid series by in situ U-Pb geochronology and Hf isotope zircon composition: The Variscan Montes de Toledo batholith (central Spain). Lithos, 200-201(1), 273-298. https://doi.org/10.1016/j.lithos.2014.04.013

Miller, C. F., Hanchar, J. M., Wooden, J. L., Bennett, V. C., Harrison, T. M., Wark, D. A., Foster, D. A. (1992). Source region of a granite batholiths: evidence from lower crustal xenoliths and inherited accessory minerals. Transactions of the Royal Society of Edinburgh: Earth Sciences, 83, 49-62.

Miller, C. F., McDowell, S., Mapes, R. W. (2003). Hot and cold granites? Implications of zircon saturation temperatures and preservation of inheritance. Geology, 31, 529-532.

Miller, C. F., Stoddard, E. F., Bradfish, L. J., \& Dollase, W. A. (1981). Composition of plutonic muscovite: genetic implications. Canadian Mineralogist, 19(1), 25-34.

Monier, G., Mergoil-Daniel, J., \& Labernardière, H. (1984). Générations successives de muscovites et feldspaths potassiques dans les leucogranites du massif de Millevaches (Massif Central francais). Bulletin de Minéralogie, 107(1), 55-68. https://doi.org/10.3406/bulmi.1984.7793 
839 Müller, A., Seltmann, R., Halls, C., Siebel, W., Dulski, P., Jeffries, T., Spratt, J., Kronz, A. (2006). The 840 magmatic evolution of the Land's End pluton, Cornwall, and associated pre-enrichment of metals. Ore Geology Reviews, 28, 329-367.

Nachit, H., Razafimahefa, N., Stussi, J. M., \& Carron, J. P. (1985). Composition chimique des biotites et typologie magmatique des granitoides. Comptes Rendus de l'Académie Des Sciences, Paris, Serie II, 301(11), 813-818.

Nash, W. P., \& Crecraft, H. R. (1985). Partition coefficients for trace elements in silicic magmas. Geochimica et Cosmochimica Acta, 49(11), 2309-2322. https://doi.org/10.1016/00167037(85)90231-5

Neiva, A. M. R. \& Gomes, M.E.P. (2001). Diferentes tipos de granitos e seus processos petrogenéticos: granitos hercínicos portugueses. Memórias da Academia das Ciências de Lisboa, 31, 53-95.

Neiva, A. M. R. \& Ramos, J. M. F. (2010). Geochemistry of granite aplite-pegmatite sills and petrogenetic links with granites, Guarda-Belmonte area, central Portugal. European Journal of Mineralogy, 22(6), 837-854.

Neiva, A. M. R. (1984). Geochemistry of tin-bearing granitic rocks. Chemical Geology, 43(3-4), 241256. https://doi.org/10.1016/0009-2541(84)90052-4

Neiva, A. M. R. (1994). Dating and geochemistry of tin-bearing granitic rocks and their minerals from NE of Gerez mountain, Northern Portugal. Boletín de la Sociedad Española de Mineralogía, 17, 6582.

Neiva, A. M. R. (1998). Geochemistry of highly peraluminous granites and their minerals between Douro and Tamega valleys, northern Portugal. Chemie der Erde, 58, 161-184.

Neiva, A. M. R. (2002). Portuguese granites associated with Sn-W and Au mineralizations. Bulletin of the Geological Society of Finland, 74, 79-101.

Neiva, A. M. R., Silva, P. B., Corfu, F., \& Ramos, J. M. F. (2011a). Sequential melting and fractional crystallization: Granites from Guarda-Sabugal area, central Portugal. Geochemistry, 71(3), 227245. https://doi.org/10.1016/j.chemer.2011.06.002

Neiva, A. M. R., Silva, P. B., Ramos, J. M. F. (2011b). Geochemistry of granitic aplite-pegmatite veins and sills and their minerals from the Sabugal area, central Portugal. Neues Jahrbuch für Mineralogie, 189(1), 49-74. 
868 Neiva, A. M. R., Williams, I. S., Ramos, J. M. F., Gomes, M. E. P., Silva, M. M. V. G., \& Antunes, I. M. 869

H. R. (2009). Geochemical and isotopic constraints on the petrogenesis of Early Ordovician granodiorite and Variscan two-mica granites from the Gouveia area, central Portugal. Lithos, 111(3-4), 186-202. https://doi.org/10.1016/j.lithos.2009.01.005

Nekvasil, H. (1992). Ternary feldspar crystallization in high-temperature felsic magmas. American Mineralogist, 77, 592-604.

Nguyen, T. A., Yang, X., Thi, H. V., Liu, L., \& Lee, I. (2019). Piaoac Granites Related W-Sn Mineralization, Northern Vietnam: Evidences from Geochemistry, Zircon Geochronology and Hf Isotopes. Journal of Earth Science, 30(1), 52-69. https://doi.org/10.1007/s12583-018-0865-6

Oliveira. J., Pereira, E., Piçarra, J., Young, T. \& Romano, M. (1992). O Paleozóico Inferior de Portugal: síntese da estratigrafia e da evolução paleogeográfica. In Gutiérrez Marco, J.C., Saavedra, J., Rábano, I. (Eds.), Paleozóico Inferior de Ibero-América (pp. 359-375). Badajoz: Universidad de Extremadura.

Otamendi, J. E., Nullo, F. E., Patiño Douce, A. E., Fagiano, M. (1998). Geology, mineralogy and geochemistry of syn-orogenic anatectic granites from the Achiras Complex, Córdoba, Argentina: some petrogenetic and geodynamic implications. Journal of South American Earth Sciences, 11(4), $407-423$.

Pan, X., Hou, Z., Zhao, M., Chen, G., Rao, J., Li, Y., Wei, J., \& Ouyang, Y. (2018). Geochronology and geochemistry of the granites from the Zhuxi W-Cu ore deposit in South China: Implication for petrogenesis, geodynamical setting and mineralization. Lithos, 304-307, 155-179. https://doi.org/10.1016/j.lithos.2018.01.014

Pearce, J. A., Harris, N. B. W., Tindle, A. G. (1984). Trace element discrimination diagrams for the tectonic interpretation of granitic rocks. Journal of Petrology 25, 956-983.

Pereira, M. F., Castro, A., Fernández, C., \& Rodríguez, C. (2018). Multiple Paleozoic magmatic-orogenic events in the Central Extremadura batholith (Iberian Variscan belt, Spain). Journal of Iberian Geology, 44(2), 309-333. https://doi.org/10.1007/s41513-018-0063-5

Pin, C., \& Santos Zalduegui, J. F. (1997). Sequential separation of light rare-earth elements, thorium and uranium by miniaturized extraction chromatography: Application to isotopic analyses of silicate rocks. Analytica Chimica Acta, 339(1-2), 79-89. https://doi.org/10.1016/S0003-2670(96)00499-0 
896 Poitrasson, F., Chenery, S., \& Bland, D. J. (1996). Contrasted monazite hydrothermal alteration

897

898

899

900

901

902

903

904

905

906

907

908

909

910

911

912

913

914

915

916

917

918

919

920

921

922

923

924 mechanisms and their geochemical implications. Earth and Planetary Science Letters, 145(1-4), 79-96. https://doi.org/10.1016/s0012-821x(96)00193-8

Qiu, Z., Yan, Q., Li, S., Wang, H., Tong, L., Zhang, R., Wei, X., Li, P., Wang, L., Bu, A., Bu, A., \& Yan, L. (2017). Highly fractionated Early Cretaceous I-type granites and related $\mathrm{Sn}$ polymetallic mineralization in the Jinkeng deposit, eastern Guangdong, SE China: Constraints from geochronology, geochemistry, and Hf isotopes. Ore Geology Reviews, 88, 718-738. https://doi.org/10.1016/j.oregeorev.2016.10.008

Rieder, M., Cavazzini, G., D’Yakonov, Y. S., Frank-Kamenetskii, V. A., Gottardi, G., Guggenheim, S., Koval', P. V., Müller, G., Neiva, A. M. R., Radoslovich, E. W., Robert, J. L., Sassi, F. P., Takeda, H., Weiss, Z., \& Wones, D. R. (1998). Nomenclature of the micas. Canadian Mineralogist, 36(3), 905-912. https://doi.org/10.1180/minmag.1999.063.2.13

Roda-Robles, E., Villaseca, C., Pesquera, A., Gil-Crespo, P. P., Vieira, R., Lima, A., \& Garate-Olave, I. (2018). Petrogenetic relationships between Variscan granitoids and Li-(F-P)-rich aplite-pegmatites in the Central Iberian Zone: Geological and geochemical constraints and implications for other regions from the European Variscides. Ore Geology Reviews, 95, 408-430. https://doi.org/10.1016/j.oregeorev.2018.02.027

Romer, R. L., \& Kroner, U. (2016). Phanerozoic tin and tungsten mineralization-Tectonic controls on the distribution of enriched protoliths and heat sources for crustal melting. Gondwana Research, 31, 60-95. https://doi.org/10.1016/j.gr.2015.11.002

Romer, R. L., Förster, H.-J., \& Hahne, K. (2012). Strontium isotopes - A persistent tracer for the recycling of Gondwana crust in the Variscan orogen. Gondwana Research, 22(1), 262-278. https://doi.org/10.1016/j.gr.2011.09.005

Ruiz, C., Fernández-Leyva, C., \& Locutura, J. (2008). Geochemistry, geochronology and mineralisation potential of the granites in the Central Iberian Zone: The Jalama batholith. Chemie Der Erde, 68(4), 413-429. https://doi.org/10.1016/j.chemer.2006.11.001

Schärer, U. (1984). The effect of initial ${ }^{230} \mathrm{Th}$ disequilibrium on young U-Pb ages: the Makalu case, Himalaya. Earth and Planetary Science Letters, 67(2), 191-204. https://doi.org/10.1016/0012$821 X(84) 90114-6$ 
925 Silva, A. F., Rebelo, J. A. \& Ribeiro, M. L. (1989). Notícia explicativa da Folha 11-C (Torre de Moncorvo). Serviços Geológicos de Portugal, Lisboa.

927

928

929

930

931

932

933

934

935

936

937

938

939

940

941

942

943

944

945

946

947

948

949

950
Silva, A. F., Rebelo, J. A., Santos, A.J., Cardoso, F., Ribeiro, M.L., Ribeiro, A., Cabral, J. \& Estagiários da F.C.L. (1987/88). Carta Geológica de Portugal à escala 1:50 000 (Folha 11-C, Torre de Moncorvo). Serviços Geológicos de Portugal.

Simons, B., Andersen, J. C. Ø., Shail, R. K., \& Jenner, F. E. (2017). Fractionation of Li, Be, Ga, Nb, Ta, In, $\mathrm{Sn}, \mathrm{Sb}, \mathrm{W}$ and $\mathrm{Bi}$ in the peraluminous Early Permian Variscan granites of the Cornubian Batholith: Precursor processes to magmatic-hydrothermal mineralisation. Lithos, 278-281, 491512. https://doi.org/10.1016/j.lithos.2017.02.007

Simons, B., Shail, R. K., \& Andersen, J. C. O. (2016). The petrogenesis of the Early Permian Variscan granites of the Cornubian Batholith: Lower plate post-collisional peraluminous magmatism in the Rhenohercynian Zone of SW England. Lithos, 260, 76-94. https://doi.org/10.1016/j.lithos.2016.05.010

Smith, W. D., Darling, J. R., Bullen, D. S., Lasalle, S., Pereira, I., Moreira, H., Allen, C. J., \& Tapster, S. (2019). Zircon perspectives on the age and origin of evolved S-type granites from the Cornubian Batholith, Southwest England. Lithos, 336-337, 14-26. https://doi.org/10.1016/j.lithos.2019.03.025

Sousa, L. (2000). Estudo da fracturação e das carcterísticas físico-mecânicas de granitos da região de Trás-os-Montes com vista à sua utilização como rocha ornamental. Unpublished $\mathrm{PhD}$ thesis, University of Trás-os-Montes e Alto Douro, 479 p.

Stacey, J. S., \& Kramers, J. D. (1975). Approximation of terrestrial lead isotope evolution by a two-stage model. Earth and Planetary Science Letters, 26(2), 207-221. https://doi.org/10.1016/0012$821 X(75) 90088-6$

Steiger, R. H., \& Jäger, E. (1977). Subcommission on geochronology: Convention on the use of decay constants in geo- and cosmochronology. Earth and Planetary Science Letters, 36(3), 359-362. https://doi.org/10.1016/0012-821X(77)90060-7

Sylvester, A. G. (1998). Magma mixing, structure, and re-evaluation of the emplacement mechanism of Vradal pluton, central Telemark, southern Norway. Norsk Geologisk Tidsskrift, (78), 259-276.

Tassinari, C. C. G., Medina, J., Pinto, M. S. (1995). Rb-Sr and Sm-Nd geochronology and isotope geochemistry of Central Iberian metasedimentary rocks (Portugal). Geologie en Mijnbouw, 75, 69-79. 
954 Taylor, S. R. \& McLennan, S. M. (1985). The continental crust: its composition and evolution. Carlton:

$955 \quad$ Blackwell Scientific Publication.

956 Teixeira, R. J. S. (2008). Mineralogia, petrologia e geoquímica dos granitos e seus encraves da região de 957 Carrazeda de Ansiães. Unpublished PhD thesis, University of Trás-os-Montes e Alto Douro, 430 p. 958 Teixeira, R. J. S., Coke, C. Dias, R. \& Gomes, M. E. P. (2012b). U-Pb geochronology of detrital zircons 959 from a metaconglomerate of the Formation of São Domingos (Group of Douro),

Teixeira, R. J. S., Coke, C., Gomes, M. E. P. \& Corfu, F. (2013a). ID-TIMS U-Pb ages of TremadocianFloian ash-fall tuff beds from Marão and Eucísia areas, Northern Portugal. William Smith Meeting 2013: The First Century of Isotope Geochronology: the Legacy of Frederick Soddy \& Arthur Holmes - Abstract Book, 152-154.

Teixeira, R. J. S., Coke, C., Gomes, M. E. P., Dias, R. \& Martins, L. O. (2013b). U-Pb geochronology of detrital zircons from metasedimentary rocks from Formation of Desejosa, Serra do Marão, Portugal. (Goldschmidt Conference Abstract). Mineralogical Magazine, 77(5), 2318.

Teixeira, R. J. S., Neiva, A. M. R., Gomes, M. E. P., Corfu, F., Cuesta, A., \& Croudace, I. W. (2012a). The role of fractional crystallization in the genesis of early syn-D 3, tin-mineralized Variscan twomica granites from the Carrazeda de Ansiães area, northern Portugal. Lithos, 153, 177-191. https://doi.org/10.1016/j.lithos.2012.04.024

Teixeira, R. J. S., Neiva, A. M. R., Silva, P. B., Gomes, M. E. P., Andersen, T., \& Ramos, J. M. F. (2011). Combined U-Pb geochronology and Lu-Hf isotope systematics by LAM-ICPMS of zircons from granites and metasedimentary rocks of Carrazeda de Ansiães and Sabugal areas, Portugal, to constrain granite sources. Lithos, 125(1-2), 321-334. https://doi.org/10.1016/j.lithos.2011.02.015

Teixeira, R. J. S., Urbano, E. E. M. C., Gomes, M. E. P., Meireles, C. A., Corfu, F., Santos, J. F., Azevedo, M. R., \& Sá, A. A. (2015). Interbedded quartz-muscovite layers in the ferriferous quartzites of the Lower Ordovician deposits of Moncorvo synclinorium (NE Portugal): An example of volcanogenic metasedimentary deposits?. Comunicacões Geológicas, 102 (Special Is), 31-39.

Tischendorf, G., Gottesmann, B., Foster, H-J. \& Trumbull, R. B. (1997). On Li-bearing micas: estimating Li from electron microprobe analyses and an improved diagram for graphical representation. Mineralogical Magazine, 61, 809-834. 
983 Valle Aguado, B., Azevedo, M. R., Schaltegger, U., Martínez Catalán, J. R., \& Nolan, J. (2005). U-Pb 984 zircon and monazite geochronology of Variscan magmatism related to syn-convergence extension in Central Northern Portugal. Lithos, 82(1-2 SPEC. ISS.), 169-184. https://doi.org/10.1016/j.lithos.2004.12.012

Villaseca, C., Barbero, L., Rogers, G. (1998). Crustal origin of Hercynian peraluminous granitic batholiths of Central Spain: petrological, geochemical and isotopic ( $\mathrm{Sr}, \mathrm{Nd})$ constraints. Lithos, 43, $55-79$.

Villaseca, C., Downes, H., Pin, C., Barbero, L. (1999). Nature and Composition of the Lower Continental Crust in Central Spain and the Granulite-Granite Linkage: Inferences from Granulitic Xenoliths. Journal of Petrology, 40(10), 1465-1496.

Villaseca, C., Merino, E., Oyarzun, R., Orejana, D., Pérez-Soba, C., \& Chicharro, E. (2014). Contrasting chemical and isotopic signatures from Neoproterozoic metasedimentary rocks in the Central Iberian Zone (Spain) of pre-Variscan Europe: Implications for terrane analysis and Early Ordovician magmatic belts. Precambrian Research, 245, 131-145. https://doi.org/10.1016/j.precamres.2014.02.006

Villaseca, C., Pérez-Soba, C., Merino, E., Orejana, D., López-García, J. A., \& Billstrom, K. (2008). Contrasting crustal sources for peraluminous granites of the segmented Montes de Toledo Batholith (Iberian Variscan Belt). Journal of Geosciences, 53(3-4), 263-280. https://doi.org/10.3190/jgeosci.035

Wang, F., Bagas, L., Jiang, S., \& Liu, Y. (2017). Geological, geochemical, and geochronological characteristics of Weilasituo Sn-polymetal deposit, Inner Mongolia, China. Ore Geology Reviews, 80, 1206-1229. https://doi.org/10.1016/j.oregeorev.2016.09.021

Wang, L.-X., Ma, C.-Q., Zhang, C., Zhang, J.-Y., \& Marks, M. A. W. (2014). Genesis of leucogranite by prolonged fractional crystallization: A case study of the Mufushan complex, South China. Lithos, 206-207(1), 147-163. https://doi.org/10.1016/j.lithos.2014.07.026

Wasserburg, G. J., Jacobsen, S. B., De Paolo, D. J., McCullock, M. T. \& Wen, T. (1981). Precise determination of $\mathrm{Sm} / \mathrm{Nd}$ ratios, $\mathrm{Sm}$ and $\mathrm{Nd}$ isotopic abundances in standard solutions. Geochimica et Cosmochimica Acta, 45, 2311-2323. 
1011 Watson, E. B. \& Harrison, T. M. (1983). Zircon saturation revisited: temperature and composition effects 1012 in a variety of crustal magma types. Earth and Planetary Science Letters, 64, 295-304.

1013 Williamson, B. J., Shaw, A., Downes, H. \& Thrillwall, M.F. (1996). Chemical constraints on the genesis 1014 of Hercynian two-mica leucogranites from the Massif Central. Chemical Geology, 127, 25-42.

1015 Xu, B., Jiang, S.-Y., Wang, R., Ma, L., Zhao, K.-D., \& Yan, X. (2015). Late Cretaceous granites from the 1016 giant Dulong Sn-polymetallic ore district in Yunnan Province, South China: Geochronology, 1017 geochemistry, mineral chemistry and Nd-Hf isotopic compositions. Lithos, 218-219, 54-72. 1018 https://doi.org/10.1016/j.lithos.2015.01.004

1019 Yurimoto, H., Duke, E. F., Papike, J.J. \& Shearer, C. K. (1990). Are discontinuous chondrite-normalized 1020

REE patterns in pegmatitic granitic systems the results of monazite fractionation? Geochimica et Cosmochimica Acta, 54, 2141-2145.

Zhang, L.-X., Wang, Q., Zhu, D.-C., Li, S.-M., Zhao, Z.-D., Zhang, L.-L., Chen, Y., Liu, S.-A., Zheng, Y.-C., Wang, R., Wang, R., \& Liao, Z.-L. (2019). Generation of leucogranites via fractional crystallization: A case from the Late Triassic Luoza batholith in the Lhasa Terrane, southern Tibet. 1026 1027 1028 1029 1030 1031 1032 1033 1034 1035 1036 1037 1038 1039 


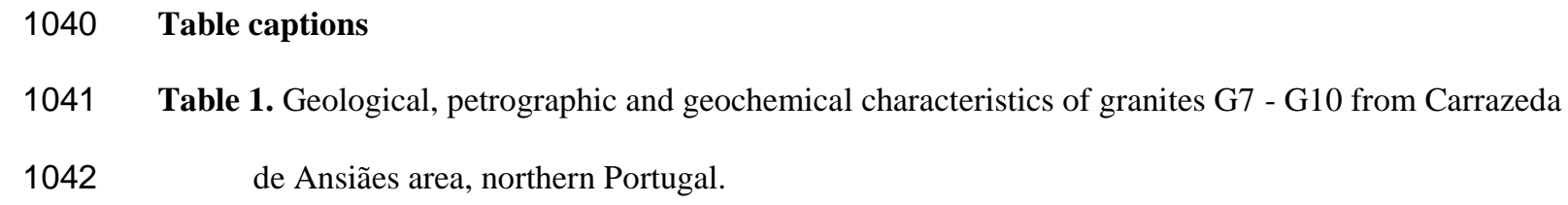

1041 Table 1. Geological, petrographic and geochemical characteristics of granites G7 - G10 from Carrazeda 1042 de Ansiães area, northern Portugal.

1043 Table 2. Average modal compositions and average whole rock chemical analyses in wt.\% and trace 1044 elements in ppm of granites G7 - G10 from Carrazeda de Ansiães area, northern Portugal.

1045 Table 3. U-Pb data of zircon and monazite from granites G7 - G10 of Carrazeda de Ansiães area, 1046 northern Portugal.

1047

1048

1049

\section{Supplemental electronic table captions}

1050 Supplemental electronic data Table 1. Representative analyses of rare earth elements (ppm) of granites 1051 G7 - G10 from Carrazeda de Ansiães area, northern Portugal.

1052 Supplemental electronic data Table 2. Whole rock Rb-Sr, Sm-Nd and oxygen isotopic values of 1053 granites G7 - G10 from Carrazeda de Ansiães area, northern Portugal.

Supplemental electronic data Table 3. Average chemical analyses (EPMA) in wt.\% and trace elements (laser ablation ICP-MS) in ppm of feldspars of granites G7 - G10 from Carrazeda de Ansiães area, 1056 northern Portugal.

Supplemental electronic data Table 4. Average chemical analyses (EPMA) in wt.\% and trace elements (laser ablation ICP-MS) in ppm of biotites and muscovites of granites G7 - G10 from Carrazeda de 1059 Ansiães area, northern Portugal.

Supplemental electronic data Table 5. Electron microprobe analyses in wt.\% and cations based on 6 1061 oxygens of ilmenites of granites G7 - G10 from Carrazeda de Ansiães area, northern Portugal.

Supplemental electronic data Table 6. Results of the fractional crystallization modeling of granites G8, G9 and G10 from Carrazeda de Ansiães area, northern Portugal. 


\section{Figure captions}

Fig. 1. a) Distribution of Variscan syn- to post-kinematic granites from northern and central Portugal (Azevedo and Valle Aguado, 2006) and location of the Carrazeda de Ansiães area; b) Geological map of the area (after Silva et al., 1987/88). 1- metasedimentary formations of the Douro Group; 2- early syn- $\mathrm{D}_{3}$ Variscan granites (Group I); G7- medium- to coarse-grained slightly porphyritic muscovite > biotite granite; G8- medium-grained porphyritic biotite $\approx$ muscovite granite; G9- Medium-grained porphyritic granite muscovite > biotite granite; G10- Medium-grained slightly porphyritic muscovitedominant granite; 3- late syn- $\mathrm{D}_{3}$ Variscan granites; 4- rhyolitic porphyry, aplite, pegmatite and quartz veins; 5- lamprophyre and microgabbro; 6- sedimentary cover; 7- geological contact; 8- fault; 9probable fault; 10- sampling sites for $\mathrm{U}-\mathrm{Pb}$ dating.

Fig. 2. a) Magmatic foliation in granite G9 defined by feldspar phenocrysts; b) Surmicaceous enclaves in granite G8, oriented parallel to the $\mathrm{N} 55-60^{\circ} \mathrm{W}$ magmatic foliation; c) Magmatic foliation in granite G8 defined by biotite. The quartz crystals of the matrix are only slightly deformed (photomicrograph in $\times$ nicols); d) Round-shaped enclave of granite G7 in granite G8; e) Irregular-shaped tonalitic enclave in granite G8; f) Fine-grained monzogranite enclave, partially enclosing phenocrysts of the host granite G9; g) Microfracturing of plagioclase in granite G10. One of the microfractures is filled with quartz (photomicrograph in $\times$ nicols); h) Muscovite from G10 granite affected by a microfracture and microscale "kink" type folding. The microfracture extends to the adjacent plagioclase crystal, subdividing into multiple branches (photomicrograph in $\times$ nicols); i) BSE image of an isolated crystal of apatite from granite G9, with inclusions of zircon, monazite and ilmenite. Abbreviations: Ap-apatite, Btbiotite, Ilm- ilmenite; Mcl- microcline, Ms- muscovite, Pl- plagioclase, Qtz- quartz and Zrn- zircon.

Fig. 3. Variation diagrams for whole rock major and trace element concentrations in granites G7 - G10 from Carrazeda de Ansiães area. The samples of granite G7 define one trend, whereas granites G8, G9 and G10 define a different trend. The samples richest in $\mathrm{Rb}$ of granite $\mathrm{G} 7$ reflect some metasomatic effects and, therefore, were not considered in the curvilinear regression. 
Fig. 4. Average chondrite-normalized REE abundances for granites G7 - G10 from Carrazeda de Ansiães area, northern Portugal. Chondrite abundances from Taylor and McLennan (1985).

Fig. 5. Ocean-ridge granite-normalized (ORG) diagram of Pearce et al. (1984) and Harris et al. (1986) for granites G7 - G10 from Carrazeda de Ansiães area, northern Portugal. The shaded area corresponds to syn-collisional granites from Harris et al. (1986).

Fig. 6. Concordia diagrams displaying the U-Pb data for zircon (white ellipses) and monazite (gray ellipses) for the four units of the suite, with error ellipses drawn at $2 \sigma$, and BSE images of isolated monazite crystals. The resorbed texture of the monazite from granite G8 (d) was probably the result of an alteration process, whereas in the subhedral monazite from granite G9 there is evidence of an inherited core (e).

Fig. 7. Diagram of $\varepsilon \mathrm{Nd}_{320 \mathrm{Ma}}$ versus $\left({ }^{87} \mathrm{Sr} /{ }^{86} \mathrm{Sr}\right)_{320 \mathrm{Ma}}$ of granites $\mathrm{G} 7$ - G10 from Carrazeda de Ansiães area, northern Portugal. Results of field projections for (A) felsic peraluminous granulites (lower-crustal xenoliths; Villaseca et al., 1999); (B) metasediments from Beiras Group (Beetsma, 1995; Tassinari et al., 1996) and southern CIZ (Villaseca et al., 2014), (C) orthogneisses from the Spanish Central System (Villaseca et al., 1998), (D) pelitic peraluminous granulites (lower-crustal xenoliths; Villaseca et al., 1999), (E) metasediments from Douro Group (Teixeira et al., 2012) and northern CIZ (Villaseca et al., 1998, 2014) and (F) metasediments from Ordovician units of Central Iberian Zone and GaliciaTrás-os-Montes Zone and from Silurian units of Galicia-Trás-os-Montes (Beetsma, 1995).

Fig. 8. Whole rock Rb-Sr isochron diagram for granites G8, G9 and G10 from Carrazeda de Ansiães area, northern Portugal.

Fig. 9. Plots and trend lines of whole rock Sn versus $\mathrm{Sn}$ in: a) biotite and b) muscovite of series G8, G9 and G10 from Carrazeda de Ansiães area, northern Portugal. 
1126 Fig. 10. Correlation of $\log \mathrm{Rb} / \mathrm{Sr}-\log \mathrm{Sn}$ for series G8, G9 and G10 from Carrazeda de Ansiães area, 1127 northern Portugal. Global reference fields from Lehman (1990).

\section{Supplemental electronic figure captions}

Supplemental electronic Fig. 1. Variation diagrams for selected major and trace elements, showing trend lines for the differentiation series G8, G9 and G10.

Supplemental electronic Fig. 2. Variation diagrams of selected major and trace element abundances of: a) matrix microcline and b) matrix plagioclase plotted against the whole rock $\mathrm{Fe}_{2} \mathrm{O}_{3} \mathrm{t}$ abundance of granites G7 - G10 from Carrazeda de Ansiães area, northern Portugal, showing trend lines for differentiation series G8, G9 and G10.

Supplemental electronic Fig. 3. Variation diagrams of selected major and trace elements of: a) biotite, b) muscovite and c) ilmenite against the whole rock $\mathrm{Fe}_{2} \mathrm{O}_{3} \mathrm{t}$ abundance of granites $\mathrm{G} 7$ - G10 from Carrazeda de Ansiães area, northern Portugal, showing trend lines for differentiation series G8, G9 and G10.

Supplemental electronic Fig. 4. Plot of modal quartz, K-feldspar, plagioclase and biotite of cumulate and calculated $\mathrm{Sr}, \mathrm{Ba}$ and $\mathrm{Rb}$ concentrations in granites G8, G9 and G10 from Carrazeda de Ansiães area, northern Portugal versus the weight fraction (FR) of melt remaining during fractional crystallization and comparison of the measured (solid regression line) and calculated (dashed regression line) concentrations of $\mathrm{Sr}, \mathrm{Ba}$ and $\mathrm{Rb}$. The model supports fractional crystallization. 
Table 1

Geological, petrographic and geochemical characteristics of granites G7 - G10 from Carrazeda de Ansiães area, northern Portugal

\begin{tabular}{|c|c|c|c|c|c|}
\hline Granites / Location & Mineralogy & $\begin{array}{l}\text { Texture and average } \\
\text { dimensions for } \\
\text { phenocrysts / Enclaves }\end{array}$ & Number, shape, size and deformation of the intrusions & $\begin{array}{l}\text { Geochemical } \\
\text { fingerprints }\end{array}$ & Source character and isotopes \\
\hline $\begin{array}{l}\text { General features of } \\
\text { granites } G 7-G 10\end{array}$ & $\begin{array}{l}\text { Quartz, plagioclase, microperthitic } \\
\text { microcline, biotite, some chlorite, } \\
\text { muscovite, tourmaline, zircon, } \\
\text { apatite, monazite, ilmenite, rutile } \\
\text { and anatase. }\end{array}$ & $\begin{array}{l}\text { Subhedral granular } \\
\text { texture, containing } \\
\text { feldspar phenocrysts. }\end{array}$ & & $\begin{array}{l}\text { Peraluminous and } \\
\text { alkali-calcic. }\end{array}$ & $\begin{array}{l}\text { Granites G7 and G8 are of S- } \\
\text { type and result from the } \\
\text { sequential partial melting of } \\
\text { the same metassedimentary } \\
\text { material. }\end{array}$ \\
\hline $\begin{array}{l}\text { Granite G7 } \\
\text { Along a WNW-ESE } \\
\text { alignment, from } \\
\text { Parambos/Carrazeda } \\
\text { de Ansiães to } \\
\text { Lousa. }\end{array}$ & $\begin{array}{l}\text { Muscovite > biotite granite. } \\
\text { Contains sillimanite. }\end{array}$ & $\begin{array}{l}\text { Medium- to coarse- } \\
\text { grained slightly } \\
\text { porphyritic granite; up to } \\
2.5 \times 0.9 \mathrm{~cm} . \\
\text { Surmicaceous and } \\
\text { metasedimentary xenoliths } \\
\text { and "schlieren". }\end{array}$ & $\begin{array}{l}\text { Crops out as a } 81 \mathrm{~km}^{2} \text { WNW-ESE trending body that } \\
\text { intruded Douro Group metasediments and partially } \\
\text { surrounds the early syn- } \mathrm{D}_{3} \text { granites } \mathrm{G} 3, \mathrm{G} 4, \mathrm{G} 5 \text { and G6. } \\
\text { A N50-60\% magmatic foliation is defined by biotite } \\
\text { and more rarely by feldspar phenocrysts. This granite is } \\
\text { affected by a NNE-SSW fracture system. }\end{array}$ & $\begin{array}{l}\text { ASI: } 1.23-1.38 \\
\text { Normative } \\
\text { corundum: } 2.79- \\
4.36 \% \\
\text { इREE: } 101.1 \mathrm{ppm}\end{array}$ & $\begin{array}{l}\text { Age: } 317.8 \pm 0.5 \mathrm{Ma} \\
\left({ }^{87} \mathrm{Sr} r^{86} \mathrm{Sr}\right)_{\mathrm{i}}=0.7156 \pm 0.0005 \\
\varepsilon \mathrm{Nd}_{\mathrm{t}}=-8.5 \\
\delta^{18} \mathrm{O}=11.35-11.62 \%\end{array}$ \\
\hline $\begin{array}{l}\text { Granite } G 8 \\
\text { Around and W of } \\
\text { Quinta das Vinhas, } \\
\text { and S of Besteiros, } \\
\text { to the } S \text { and centre } \\
\text { of the area, } \\
\text { respectively. }\end{array}$ & $\begin{array}{l}\text { Biotite } \approx \text { muscovite granite } \\
\text { Contains sillimanite. }\end{array}$ & $\begin{array}{l}\text { Medium-grained } \\
\text { porphyritic granite; from } 1 \\
\times 0.4 \mathrm{~cm} \text { to } 2.4 \times 0.8 \mathrm{~cm} \text {. } \\
\text { Surmicaceous, } \\
\text { metasedimentary } \\
\text { xenoliths, monzogranite } \\
\text { enclaves and granite } \mathrm{G} 7 \\
\text { enclaves. }\end{array}$ & $\begin{array}{l}\text { Three distinct bodies, one of } 1.5 \mathrm{~km}^{2} \text { in the centre of the } \\
\text { area with a WNW-ESE elongation, and two of } 0.85 \mathrm{~km}^{2} \\
\text { and } 0.25 \mathrm{~km}^{2} \text { in the S. This homogeneous granite type } \\
\text { intruded Douro Group metasediments and partially } \\
\text { surrounds granite G7, showing sharp and fault contacts } \\
\text { locally filled with aplite. It has a magmatic N55-60贯 } \\
\text { foliation defined by oriented feldspar phenocrysts, } \\
\text { biotite and, locally, by surmicaceous enclaves and } \\
\text { xenoliths. }\end{array}$ & $\begin{array}{l}\text { ASI: } 1.22-1.39 \\
\text { Normative } \\
\text { corundum: } 2.85- \\
4.39 \% \\
\text { ¿REE: } 286.9 \mathrm{ppm}\end{array}$ & $\begin{array}{l}\text { Age: } 316.8 \pm 1.3 \mathrm{Ma} \\
\left({ }^{87} \mathrm{Sr}{ }^{86} \mathrm{Sr}\right)_{\mathrm{i}}=0.7155 \pm 0.0007 \\
\varepsilon \mathrm{Ed}_{\mathrm{t}}=-8.4 \\
\delta^{18} \mathrm{O}=11.12-11.76 \%\end{array}$ \\
\hline $\begin{array}{l}\text { Granite } G 9 \\
\text { Around Campelos } \\
\text { and SW of } \\
\text { Marzagão in the } \\
\text { SW; SE of Fonte } \\
\text { Longa in the centre } \\
\text { and SE of Lousa in } \\
\text { the SE of the area. }\end{array}$ & $\begin{array}{l}\text { Muscovite > biotite granite. } \\
\text { Contains sillimanite. }\end{array}$ & 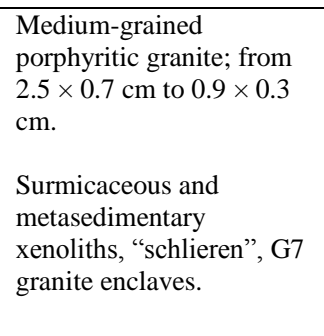 & $\begin{array}{l}\text { A main body of } 24 \mathrm{~km}^{2}, \text { with an approximated NW-SW } \\
\text { elongation, and a smaller body of } 1 \mathrm{~km}^{2} \text { in the } \mathrm{SW} \text {. In } \\
\text { the centre of the area there is another body of } 1 \mathrm{~km}^{2} \text {, } \\
\text { and a fourth body of } 2.5 \mathrm{~km}^{2} \text { occurs to the SE of the } \\
\text { area. This granite type intruded Douro Group } \\
\text { metasediments and partially surrounds the early syn-D } \\
\text { granites G3 and G5. This granite unit shows frequent } \\
\text { sharp intrusive contacts with granite G7, but faulted } \\
\text { contacts also occur. A N50-60 } 60^{\circ} \mathrm{W} \text { magmatic foliation is } \\
\text { defined by feldspar phenocrysts and biotite. }\end{array}$ & $\begin{array}{l}\text { ASI: } 1.25-1.33 \\
\text { Normative } \\
\text { corundum: } 2.96- \\
3.69 \% \\
\text { इREE: } 189.1 \mathrm{ppm}\end{array}$ & $\begin{array}{l}\text { Age: } 316.6 \pm 0.5 \mathrm{Ma} \\
\left.{ }^{87} \mathrm{Sr}{ }^{86} \mathrm{Sr}\right)_{\mathrm{i}}=0.7151 \pm 0.0009 \\
\varepsilon \mathrm{Nd}_{\mathrm{t}}=-8.3 \\
\delta^{18} \mathrm{O}=11.10-11.33 \%\end{array}$ \\
\hline $\begin{array}{l}\text { Granite G10 } \\
\text { Around the } \\
\text { geodesic vertice of } \\
\text { Arejadouro and at } \\
\text { NW of Pinhal do } \\
\text { Douro in the S. } \\
\text { Around Castelo de } \\
\text { Ansiães in the W. }\end{array}$ & Muscovite-dominant granite. & $\begin{array}{l}\text { Medium-grained slightly } \\
\text { porphyritic granite; }(2 \times \\
0.7 \mathrm{~cm} \text { to } 1 \times 0.7 \mathrm{~cm}) \\
\text { Absence of enclaves. }\end{array}$ & $\begin{array}{l}\text { Three distinct homogeneous bodies, two of } 4 \mathrm{~km}^{2} \text { and } 6 \\
\mathrm{~km}^{2} \text { in the } \mathrm{S} \text {, and a third of } 0.4 \mathrm{~km}^{2} \text { in the } \mathrm{W} \text {, show a } \\
\text { faint magmatic } \mathrm{N} 60^{\circ} \mathrm{W} \text { foliation defined by oriented } \\
\text { feldspar phenocrysts and biotite. This granite intruded } \\
\text { Douro Group metasediments and granite } \mathrm{G} 7 \text {, and } \\
\text { partially surrounds the early syn- } \mathrm{D}_{3} \text { granite } \mathrm{G} 4 \text { and the } \\
\text { granite } \mathrm{G} 9 \text {, showing fault contacts. It occurs associated } \\
\text { to NNE-SSW fault zones and it is affected by N60-70 } \\
\mathrm{W} \text { and N40-50 E secondary joints and strong brittle } \\
\text { deformation. Typically, it is intensely weathered. }\end{array}$ & $\begin{array}{l}\text { ASI: } 1.29-1.34 \\
\text { Normative } \\
\text { corundum: } 3.27- \\
3.94 \% \\
\text { IREE: } 64.2 \mathrm{ppm}\end{array}$ & $\begin{array}{l}\text { Age: } 316.2 \pm 0.7 \mathrm{Ma} \\
\left({ }^{87} \mathrm{Sr}{ }^{86} \mathrm{Sr}\right)_{\mathrm{i}}=0.7147 \pm 0.0011 \\
\varepsilon \mathrm{Nd}_{\mathrm{t}}=-8.4 \\
\delta^{18} \mathrm{O}=10.93 \%\end{array}$ \\
\hline
\end{tabular}


Table 2

Average modal compositions and average whole-rock chemical analyses in wt.\% and trace elements in ppm of granites G7 - G10 from the Carrazeda de Ansiães area, northern Portugal

\begin{tabular}{|c|c|c|c|c|c|c|c|c|}
\hline & G7 & $\sigma$ & G8 & $\sigma$ & G9 & $\sigma$ & G10 & $\sigma$ \\
\hline Quartz & 30.6 & 1.4 & 30.2 & 3.1 & 31.6 & 1.5 & 31.9 & 1.2 \\
\hline Plagioclase & 31.6 & 2.5 & 27.8 & 2.1 & 29 & 1.6 & 32.4 & 1.8 \\
\hline Microcline & 22.4 & 2 & 21.9 & 2 & 22.4 & 2.8 & 20.3 & 1.4 \\
\hline Biotite & 5.1 & 0.5 & 9.7 & 2.1 & 6.1 & 0.5 & 2.3 & 0.3 \\
\hline Muscovite & 9.8 & 1.8 & 9.7 & 2.2 & 10.3 & 1.1 & 12.5 & 1.1 \\
\hline Tourmaline & 0.2 & 0.3 & - & - & 0.1 & 0.1 & 0.1 & 0.1 \\
\hline Apatite & 0.4 & 0.1 & 0.5 & 0.1 & 0.4 & 0.1 & 0.6 & 0.2 \\
\hline Other & - & - & 0.2 & 0.1 & 0.2 & 0.1 & - & - \\
\hline $\mathrm{n}$ & 6 & & 3 & & 3 & & 3 & \\
\hline $\mathrm{SiO}_{2}$ & 72.13 & 0.43 & 69.98 & 1.19 & 71.55 & 0.50 & 73.35 & 0.48 \\
\hline $\mathrm{TiO}_{2}$ & 0.21 & 0.04 & 0.45 & 0.07 & 0.31 & 0.02 & 0.13 & 0.02 \\
\hline $\mathrm{Al}_{2} \mathrm{O}_{3}$ & 15.01 & 0.31 & 15.47 & 0.35 & 14.86 & 0.24 & 14.80 & 0.12 \\
\hline $\mathrm{Fe}_{2} \mathrm{O}_{3}$ & 0.48 & 0.11 & 0.68 & 0.17 & 0.48 & 0.11 & 0.38 & 0.08 \\
\hline $\mathrm{FeO}$ & 1.03 & 0.11 & 1.76 & 0.31 & 1.31 & 0.10 & 0.67 & 0.05 \\
\hline $\mathrm{MnO}$ & 0.03 & 0.01 & 0.03 & 0.00 & 0.03 & 0.00 & 0.03 & 0.01 \\
\hline $\mathrm{MgO}$ & 0.40 & 0.06 & 0.76 & 0.15 & 0.50 & 0.04 & 0.23 & 0.03 \\
\hline $\mathrm{CaO}$ & 0.65 & 0.06 & 0.82 & 0.07 & 0.72 & 0.03 & 0.51 & 0.03 \\
\hline $\mathrm{Na}_{2} \mathrm{O}$ & 3.50 & 0.21 & 3.06 & 0.20 & 3.19 & 0.15 & 3.69 & 0.16 \\
\hline $\mathrm{K}_{2} \mathrm{O}$ & 5.05 & 0.18 & 5.44 & 0.18 & 5.23 & 0.20 & 4.66 & 0.21 \\
\hline $\mathrm{P}_{2} \mathrm{O}_{5}$ & 0.33 & 0.03 & 0.35 & 0.01 & 0.33 & 0.02 & 0.34 & 0.02 \\
\hline $\mathrm{H}_{2} \mathrm{O}+$ & 0.84 & 0.22 & 0.98 & 0.07 & 1.07 & 0.06 & 1.01 & 0.07 \\
\hline $\mathrm{H}_{2} \mathrm{O}-$ & 0.33 & 0.10 & 0.30 & 0.04 & 0.30 & 0.05 & 0.26 & 0.07 \\
\hline S & 0.01 & 0.01 & 0.01 & 0.00 & 0.01 & 0.00 & 0.01 & 0.00 \\
\hline Total & 100.00 & 0.29 & 100.08 & 0.30 & 99.88 & 0.31 & 99.88 & 0.31 \\
\hline $\mathrm{O} \equiv \mathrm{S}$ & 0.01 & 0.01 & 0.00 & 0.00 & 0.00 & 0.00 & 0.00 & 0.00 \\
\hline Total & 99.99 & 0.29 & 100.08 & 0.30 & 99.88 & 0.31 & 99.88 & 0.31 \\
\hline ASI & 1.29 & 0.04 & 1.34 & 0.05 & 1.30 & 0.03 & 1.32 & 0.02 \\
\hline $\mathrm{C}$ & 3.40 & 0.43 & 3.89 & 0.52 & 3.43 & 0.25 & 3.60 & 0.21 \\
\hline $\mathrm{Cl}$ & 110 & 0 & 56 & 9 & 50 & 0 & 60 & 10 \\
\hline $\mathrm{F}$ & 1430 & 342 & 1955 & 78 & 2000 & 130 & 1673 & 345 \\
\hline $\mathrm{Ga}$ & 21 & 2 & 24 & 0 & 23 & 1 & 22 & 1 \\
\hline $\mathrm{Cr}$ & 34 & 8 & 38 & 3 & 40 & 6 & 32 & 3 \\
\hline V & 8 & 2 & 23 & 6 & 13 & 1 & 5 & 1 \\
\hline $\mathrm{Nb}$ & 14 & 2 & 13 & 1 & 12 & 1 & 16 & 1 \\
\hline $\mathrm{Zn}$ & 67 & 16 & 91 & 10 & 87 & 7 & 62 & 6 \\
\hline Sn & 20 & 3 & 10 & 2 & 15 & 2 & 31 & 4 \\
\hline $\mathrm{Li}$ & 198 & 44 & 204 & 49 & 169 & 25 & 241 & 73 \\
\hline $\mathrm{Ni}$ & 5 & 2 & 11 & 2 & 8 & 1 & 4 & 0 \\
\hline $\mathrm{Co}$ & 3 & 1 & 7 & 1 & 5 & 1 & 3 & 1 \\
\hline $\mathrm{Zr}$ & 73 & 30 & 201 & 29 & 140 & 12 & 53 & 7 \\
\hline $\mathrm{Cu}$ & 4 & 2 & 10 & 3 & 5 & 2 & 5 & 4 \\
\hline $\mathrm{Y}$ & 10 & 1 & 14 & 2 & 10 & 1 & 9 & 2 \\
\hline $\mathrm{Sr}$ & 76 & 19 & 135 & 29 & 81 & 8 & 43 & 6 \\
\hline $\mathrm{Pb}$ & 34 & 5 & 36 & 3 & 30 & 2 & 23 & 8 \\
\hline $\mathrm{Ba}$ & 212 & 57 & 444 & 88 & 263 & 26 & 103 & 32 \\
\hline $\mathrm{Rb}$ & 377 & 51 & 376 & 17 & 400 & 3 & 503 & 30 \\
\hline Cs & 47 & 9 & 26 & 6 & 33 & 6 & 61 & 10 \\
\hline W & 5 & 1 & 5 & 1 & 5 & 1 & 6 & 1 \\
\hline $\mathrm{U}$ & 12 & 5 & 11 & 2 & 11 & 2 & 13 & 6 \\
\hline Th & 12 & 6 & 35 & 4 & 26 & 2 & 7 & 3 \\
\hline $\mathrm{Hf}$ & $*$ & & 5 & 1 & 4 & 0 & $*$ & \\
\hline As & 5 & 1 & 8 & 0 & 5 & 2 & 4 & 0 \\
\hline $\mathrm{Bi}$ & 2 & 0 & $*$ & & $*$ & & 2 & 0 \\
\hline $\mathrm{n}$ & 17 & & 8 & & 10 & & 8 & \\
\hline
\end{tabular}

G7-Medium- to coarse-grained slightly porphyritic muscovite > biotite granite; G8- Medium-grained porphyritic biotite $\approx$ muscovite granite; G9- Medium-grained porphyritic muscovite > biotite granite; G10Medium-grained slightly porphyritic muscovite-dominant granite; $n$ - number of analyses; ASI- $\mathrm{Al} /[2(\mathrm{Ca}-$ $1.67 \mathrm{P})+\mathrm{Na}+\mathrm{K}] ; \mathrm{C}$ - corundum; $\sigma-$ standard deviation; - - not detected; *- below the limit of quantification. 
Table 3

U-Pb data of zircon and monazite from granites G7 - G10 of Carrazeda de Ansiães area, northern Portugal

\begin{tabular}{|c|c|c|c|c|c|c|c|c|c|c|c|c|c|c|c|c|c|c|c|}
\hline Fraction & $\begin{array}{l}\text { Mineral } \\
\text { characteristics }\end{array}$ & $\begin{array}{c}\text { Weight }^{2} \\
(\mu \mathrm{g})\end{array}$ & $\begin{array}{c}\mathrm{U}^{2} \\
(\mathrm{ppm})\end{array}$ & $\begin{array}{l}\mathrm{Pbt}^{3} \\
(\mathrm{ppm})\end{array}$ & $\mathrm{Th} / \mathrm{U}^{4}$ & $\begin{array}{l}\mathrm{Pbc}^{5} \\
(\mathrm{ppm})\end{array}$ & ${ }^{206} \mathrm{~Pb} /$ & $\begin{array}{l}{ }^{207} \mathrm{~Pb} / \\
{ }^{235} \mathrm{U}^{7}\end{array}$ & $\begin{array}{c}2 \sigma \\
(\text { abs })\end{array}$ & $\begin{array}{l}{ }^{206} \mathrm{~Pb} / \\
{ }^{238} \mathrm{U}^{7}\end{array}$ & $\begin{array}{c}2 \sigma \\
(\text { abs })\end{array}$ & $\rho^{8}$ & $\begin{array}{c}\text { Age } \\
{ }^{206} \mathrm{~Pb}^{* /} \\
{ }^{238} \mathrm{U}^{7}\end{array}$ & $\begin{array}{c}2 \sigma \\
(\mathrm{Ma})\end{array}$ & $\begin{array}{c}\text { Age } \\
{ }^{207} \mathrm{~Pb}^{* /} \\
{ }^{235} \mathrm{U}^{7}\end{array}$ & $\begin{array}{c}2 \sigma \\
(\mathrm{Ma})\end{array}$ & $\begin{array}{c}\text { Age } \\
{ }^{207} \mathrm{~Pb}^{* /} \\
{ }^{206} \mathrm{~Pb}^{* 7}\end{array}$ & $\begin{array}{c}2 \sigma \\
(\mathrm{Ma})\end{array}$ & $\begin{array}{l}\text { Disc. }^{9} \\
(\%)\end{array}$ \\
\hline \multicolumn{20}{|c|}{ Granite G7 (sample GL23) } \\
\hline 1 & $\mathrm{Z}$ eu lp in [2] & 4.0 & 754 & 40 & 0.11 & 0.74 & 2125 & 0.41127 & 0.00122 & 0.05542 & 0.00012 & 0.80 & 347.7 & 0.8 & 349.8 & 0.9 & 363.6 & 4.0 & 4.5 \\
\hline 2 & Z eu lp in [7] & 0.5 & 5638 & 295 & 0.22 & 9.44 & 1398 & 0.38481 & 0.00145 & 0.05233 & 0.00013 & 0.72 & 328.8 & 0.8 & 330.6 & 1.1 & 343.1 & 5.9 & 4.3 \\
\hline 3 & $\mathrm{Z}$ eu lp in [1] & 0.5 & 1366 & 84 & 0.57 & 8.97 & 360 & 0.37555 & 0.00458 & 0.05166 & 0.00035 & 0.59 & 324.7 & 2.2 & 323.8 & 3.4 & 316.9 & 22.2 & -2.5 \\
\hline 4 & Z eu lp b [18] & 1.0 & 6495 & 313 & 0.10 & 12.50 & 1416 & 0.36022 & 0.00121 & 0.04957 & 0.00011 & 0.72 & 311.9 & 0.7 & 312.4 & 0.9 & 316.0 & 5.3 & 1.3 \\
\hline 5 & $\mathrm{Z}$ eu lp in [8] & 0.5 & 4190 & 218 & 0.15 & 21.66 & 528 & 0.36269 & 0.00242 & 0.04964 & 0.00016 & 0.51 & 312.3 & 1.0 & 314.2 & 1.8 & 328.4 & 13.0 & 5.0 \\
\hline 6 & Mz eu eq y g [2] NA & 11.0 & 797 & 186 & 13.56 & 0.36 & 4731 & 0.36715 & 0.00091 & 0.05067 & 0.00010 & 0.90 & 318.6 & 0.6 & 317.5 & 0.7 & 309.7 & 2.4 & -3.0 \\
\hline 7 & Mz eu eq y g [7] NA & 9.0 & 2330 & 414 & 9.31 & 0.66 & 8409 & 0.36777 & 0.00085 & 0.05061 & 0.00010 & 0.95 & 318.3 & 0.6 & 318.0 & 0.6 & 315.9 & 1.7 & -0.8 \\
\hline \multicolumn{20}{|c|}{ Granite G8 (sample GQV8) } \\
\hline 8 & $Z$ sb fr y in $[8]$ & 3.0 & 589 & 42 & 1.75 & 0.13 & 2372 & 0.36992 & 0.00134 & 0.05072 & 0.00013 & 0.71 & 319.0 & 0.8 & 319.6 & 1.0 & 324.3 & 5.8 & 5.8 \\
\hline 9 & Z eu lp in [4] & 0.5 & 174 & 10 & 0.72 & 0.00 & 331 & 0.36856 & 0.00829 & 0.05026 & 0.00023 & 0.44 & 316.1 & 1.4 & 318.6 & 6.1 & 336.6 & 46.6 & 46.6 \\
\hline 10 & Z eu lp y in [1] & 0.5 & 514 & 27 & 0.59 & 0.00 & 662 & 0.36331 & 0.00418 & 0.04982 & 0.00017 & 0.44 & 313.4 & 0.9 & 314.7 & 3.2 & 324.1 & 23.5 & 23.5 \\
\hline 11 & $\mathrm{Z}$ eu lp y in [3] & 0.5 & 2634 & 135 & 0.33 & 4.28 & 1009 & 0.36176 & 0.00193 & 0.04972 & 0.00015 & 0.63 & 312.8 & 0.9 & 313.5 & 1.4 & 318.8 & 9.4 & 9.4 \\
\hline 12 & Z eu lp y in [1] & 0.5 & 894 & 48 & 0.36 & 4.00 & 363 & 0.36676 & 0.00433 & 0.04928 & 0.00015 & 0.46 & 310.1 & 1.1 & 317.2 & 3.1 & 370.3 & 24.0 & 24.0 \\
\hline 13 & $\mathrm{Z}$ eu lp y in $[\mathrm{f}]$ & 13.0 & 571 & 32 & 0.60 & 2.14 & 789 & 0.35925 & 0.00169 & 0.04922 & 0.00010 & 0.51 & 309.7 & 0.6 & 311.7 & 1.3 & 326.1 & 9.2 & 9.2 \\
\hline 14 & Mz sb eq y [1] NA & 1.0 & 199 & 55 & 15.81 & 0.17 & 315 & 0.37652 & 0.00845 & 0.05182 & 0.00025 & 0.42 & 325.7 & 1.5 & 324.5 & 6.2 & 315.9 & 46.7 & 46.7 \\
\hline \multicolumn{20}{|c|}{ Granite $G 9$ (sample GC5) } \\
\hline 15 & $\mathrm{Z}$ eu sp in [1] & 0.5 & 1929 & 203 & 0.89 & 12.11 & 659 & 0.70285 & 0.00379 & 0.08511 & 0.00024 & 0.55 & 526.6 & 1.4 & 540.5 & 2.3 & 599.7 & 9.7 & 12.7 \\
\hline 16 & Z eu sp in [1] & 0.5 & 772 & 77 & 0.12 & 0.00 & 3123 & 0.93128 & 0.00406 & 0.10585 & 0.00037 & 0.72 & 648.6 & 2.2 & 668.3 & 2.1 & 735.3 & 6.4 & 12.4 \\
\hline 17 & Z eu sp in [3] & 0.5 & 3334 & 328 & 0.45 & 3.91 & 2500 & 0.77825 & 0.00247 & 0.09394 & 0.00024 & 0.83 & 578.8 & 1.4 & 584.5 & 1.4 & 606.6 & 3.8 & 4.8 \\
\hline 18 & Z eu lp in [4] & 0.5 & 615 & 35 & 0.36 & 0.14 & 541 & 0.42120 & 0.00550 & 0.05649 & 0.00019 & 0.47 & 354.2 & 1.2 & 356.9 & 3.9 & 374.4 & 26.5 & 5.5 \\
\hline 19 & Mz eu eq y $g$ [2] NA & 8.0 & 1322 & 182 & 6.47 & 0.03 & 15200 & 0.36864 & 0.00085 & 0.05072 & 0.00010 & 0.93 & 318.9 & 0.6 & 318.6 & 0.6 & 316.5 & 1.9 & -0.8 \\
\hline 20 & Mz eu y g [2] NA & 0.5 & 26320 & 2875 & 4.50 & 9.49 & 6202 & 0.36622 & 0.00086 & 0.05043 & 0.00010 & 0.93 & 317.2 & 0.6 & 316.8 & 0.6 & 314.5 & 2.0 & -0.9 \\
\hline 21 & Mz eu eq y [2] NA & 1.0 & 5457 & 1055 & 10.55 & 1.93 & 4384 & 0.36555 & 0.00093 & 0.05024 & 0.00011 & 0.86 & 316.0 & 0.7 & 316.4 & 0.7 & 319.1 & 2.9 & 1.0 \\
\hline 22 & Mz eu eq y [4] NA & 1.0 & 3353 & 735 & 12.03 & 2.79 & 2254 & 0.37033 & 0.00106 & 0.05092 & 0.00011 & 0.78 & 320.2 & 0.6 & 319.9 & 0.8 & 317.7 & 4.0 & -0.8 \\
\hline \multicolumn{20}{|c|}{ Granite G10 (sample GAJ3) } \\
\hline 23 & $Z$ eu lp $[1]$ & 1.0 & 251 & 13 & 0.39 & 1.31 & 241 & 0.34255 & 0.00684 & 0.04686 & 0.00015 & 0.45 & 295.2 & 0.9 & 299.1 & 5.2 & 329.7 & 41.9 & 10.7 \\
\hline 24 & Z eu lp [1] & 1.0 & 575 & 25 & 0.12 & 0.90 & 577 & 0.32769 & 0.00326 & 0.04505 & 0.00015 & 0.45 & 284.1 & 0.9 & 287.8 & 2.5 & 318.1 & 20.2 & 10.9 \\
\hline 25 & Z eu lp b [4] & 4.0 & 6570 & 346 & 0.07 & 18.13 & 1218 & 0.40360 & 0.00189 & 0.05394 & 0.00019 & 0.80 & 338.7 & 1.2 & 344.3 & 1.4 & 382.0 & 6.3 & 11.6 \\
\hline 26 & Z eu lp in [1] & 0.5 & 3075 & 190 & 0.12 & 0.00 & 3160 & 0.50153 & 0.00195 & 0.06564 & 0.00021 & 0.79 & 409.8 & 1.3 & 412.7 & 1.3 & 429.1 & 5.3 & 4.6 \\
\hline 27 & Mz sb eq y g [1] NA & 8.0 & 2075 & 422 & 11.11 & 0.19 & 14873 & 0.36783 & 0.00086 & 0.05060 & 0.00010 & 0.95 & 318.2 & 0.6 & 318.0 & 0.6 & 317.0 & 1.7 & -0.4 \\
\hline 28 & Mz eu eq y g [1] NA & 6.0 & 1044 & 102 & 3.40 & 0.16 & 7278 & 0.39926 & 0.00106 & 0.05496 & 0.00013 & 0.88 & 344.9 & 0.8 & 341.1 & 0.8 & 315.3 & 2.9 & -9.6 \\
\hline 29 & Mz eu eq y [6] NA & 3.0 & 7206 & 1182 & 8.34 & 3.66 & 5284 & 0.36533 & 0.00089 & 0.05033 & 0.00010 & 0.93 & 316.5 & 0.6 & 316.2 & 0.7 & 313.6 & 2.1 & -1.0 \\
\hline 30 & Mz eu eq y g [6] NA & 1.0 & 4788 & 768 & 8.02 & 4.89 & 2221 & 0.36684 & 0.00100 & 0.05046 & 0.00010 & 0.81 & 317.3 & 0.6 & 317.3 & 0.7 & 317.3 & 3.7 & 0.0 \\
\hline
\end{tabular}


${ }^{1} \mathrm{Z}$ - zircon; Mz - monazite; eu - euhedral; sb - subhedral; eq - equant; sp - short prismatic (lenght/width $\approx 2$ - 4); lp - long prismatic (lenght/width > 4); fr - fragment; $\mathrm{b}$ - brown; $\mathrm{y}$ - yellow; $\mathrm{g}$ - green; in - inclusions; [N] - number of grains in fraction ( $\mathrm{f}>50$ grains); non abraded (all other minerals abraded); unless otherwise specified all the zircons were clear and transparent.

3,5 Weight and concentrations are known to be better than $10 \%$, except for those near and below the ca. $1 \mu \mathrm{g}$ limit of resolution of the balance.

${ }^{3} \mathrm{Total} \mathrm{Pb}$.

${ }^{4} \mathrm{Th} / \mathrm{U}$ model ratio inferred from ${ }^{208} \mathrm{~Pb} /{ }^{206} \mathrm{~Pb}$ ratio and age of sample.

${ }^{5}$ Total common $\mathrm{Pb}$ in sample (initial + blank)

${ }^{6}$ Raw data corrected for fractionation and blank

Corrected for fractionation, spike, blank and initial common $\mathrm{Pb}$; error calculated by propagating the main sources of uncertainity; initial common $\mathrm{Pb}$ corrected using Stacey and Kramers (1975) model $\mathrm{Pb}$.

(Rho) - Error correlation factor.

${ }^{9}$ Degree of discordancy. 


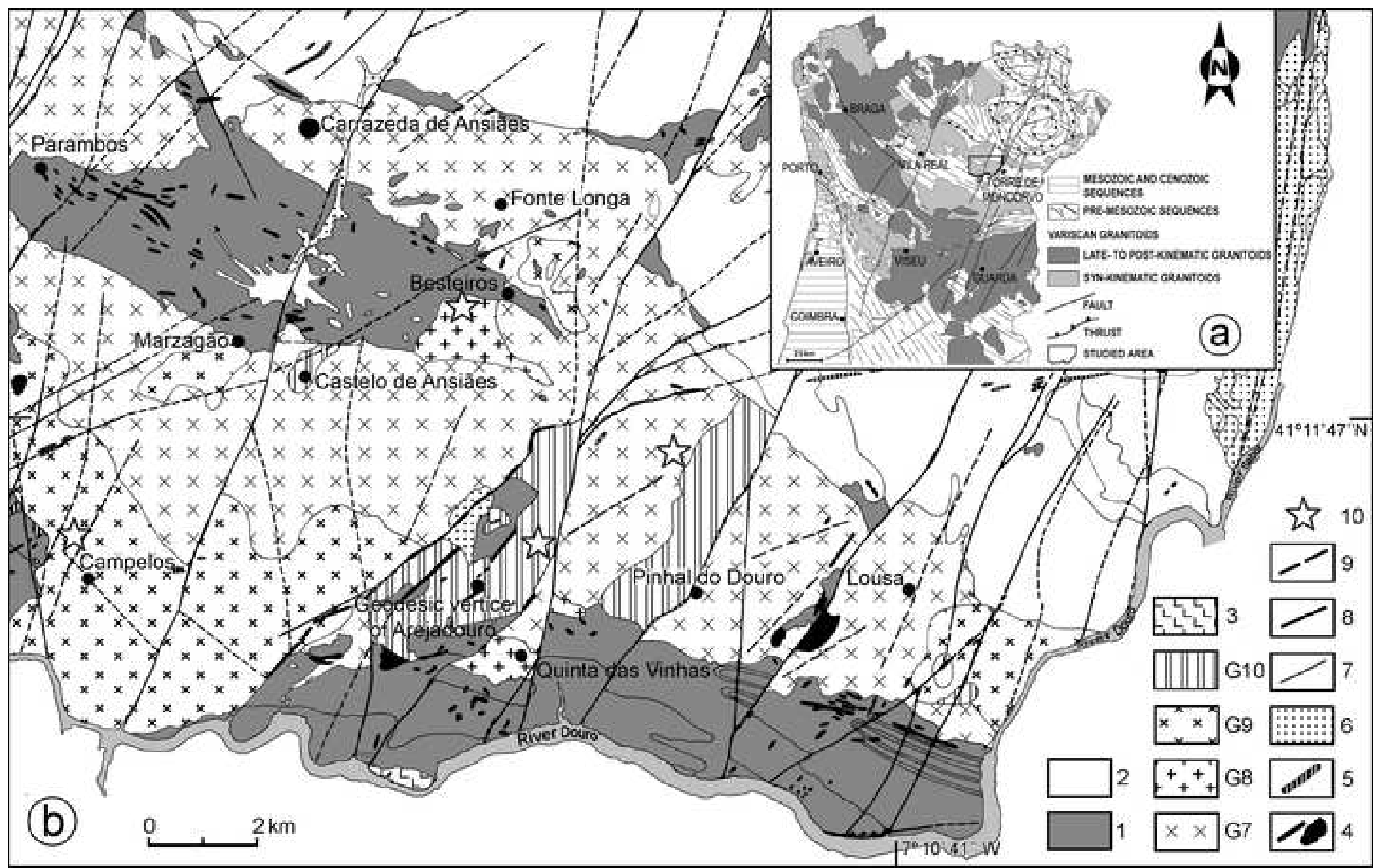



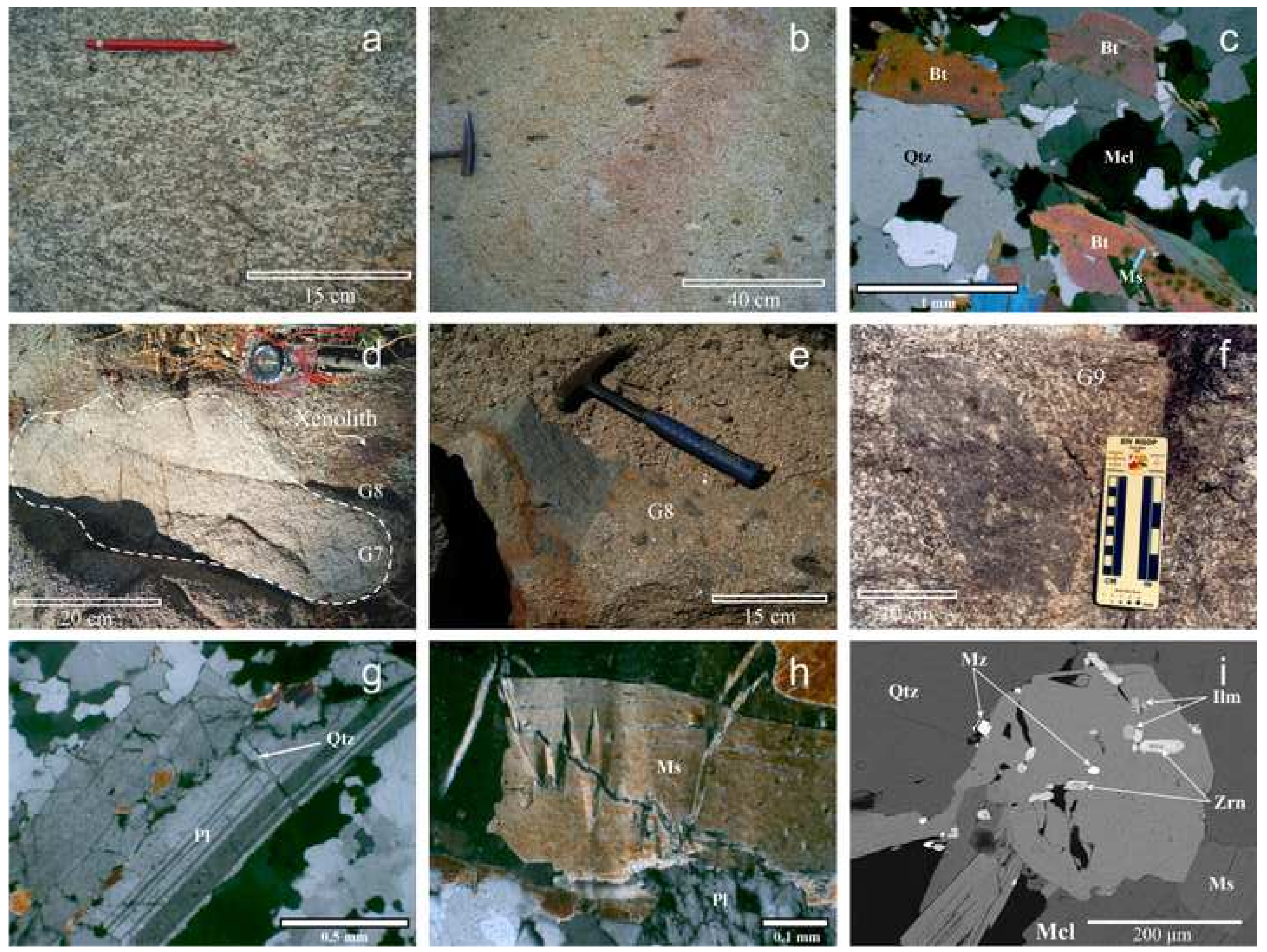

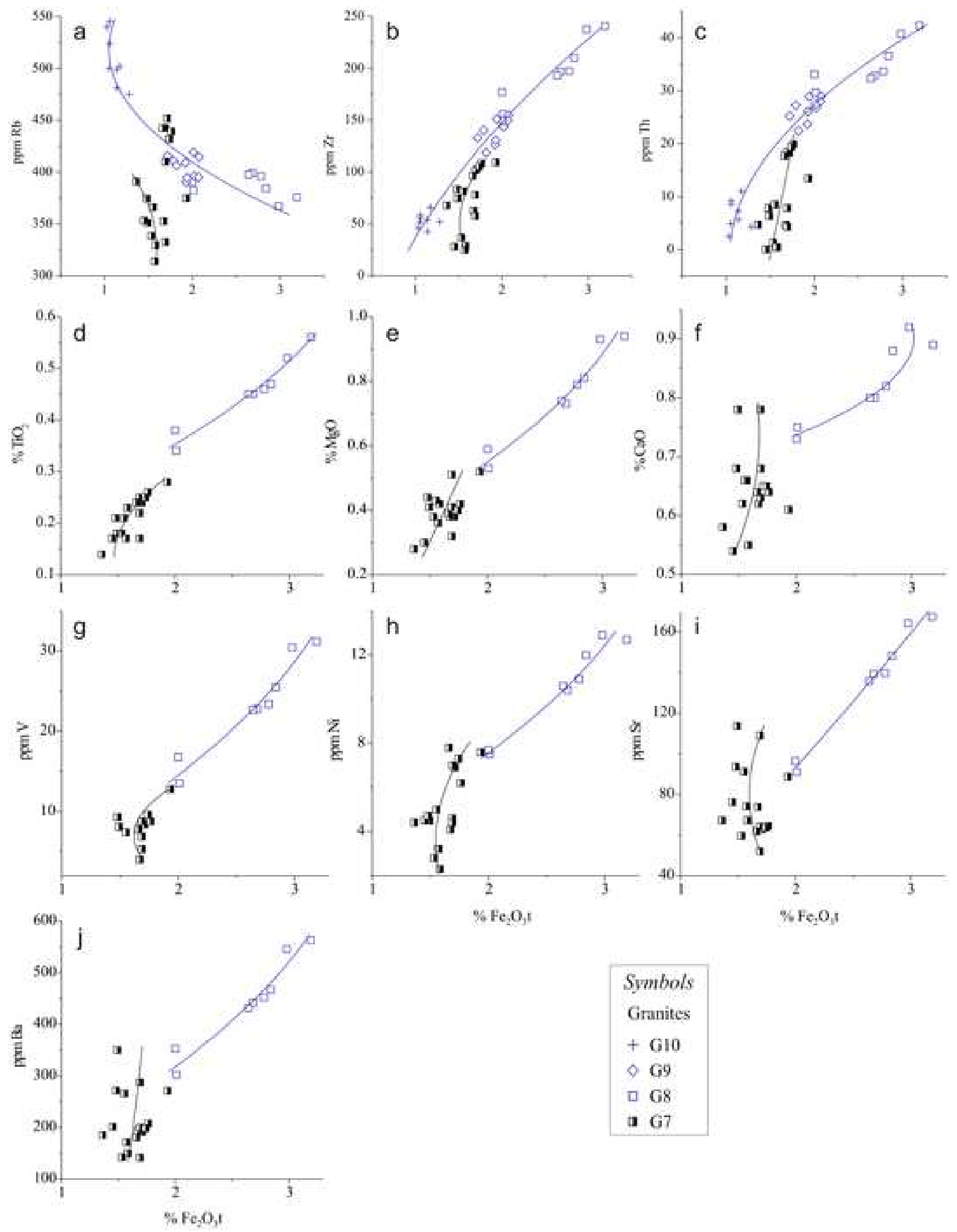

\begin{tabular}{|l|}
\hline Symbo/s \\
Granites \\
+ G10 \\
0 G9 \\
G 8 \\
a G7
\end{tabular}




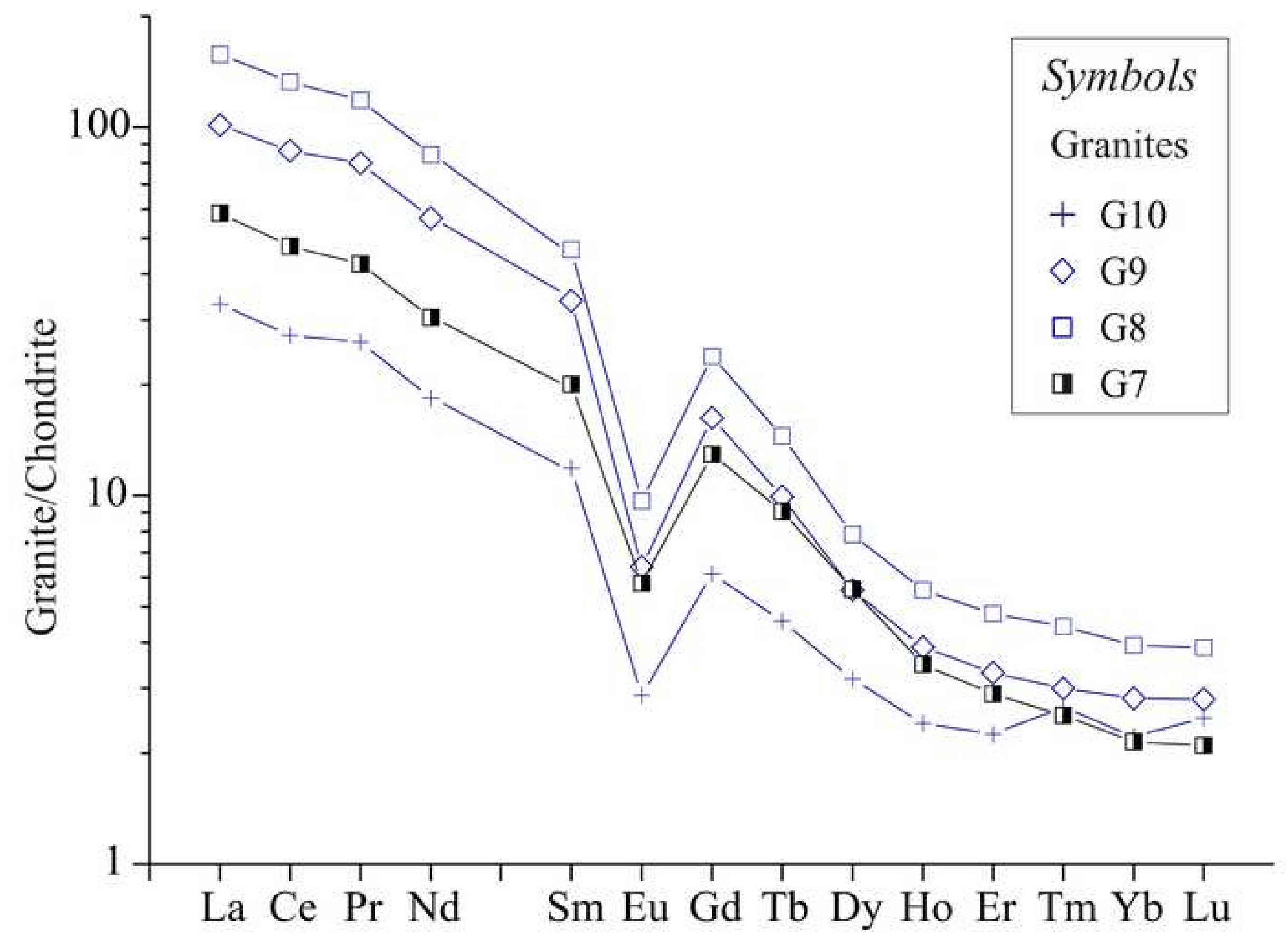




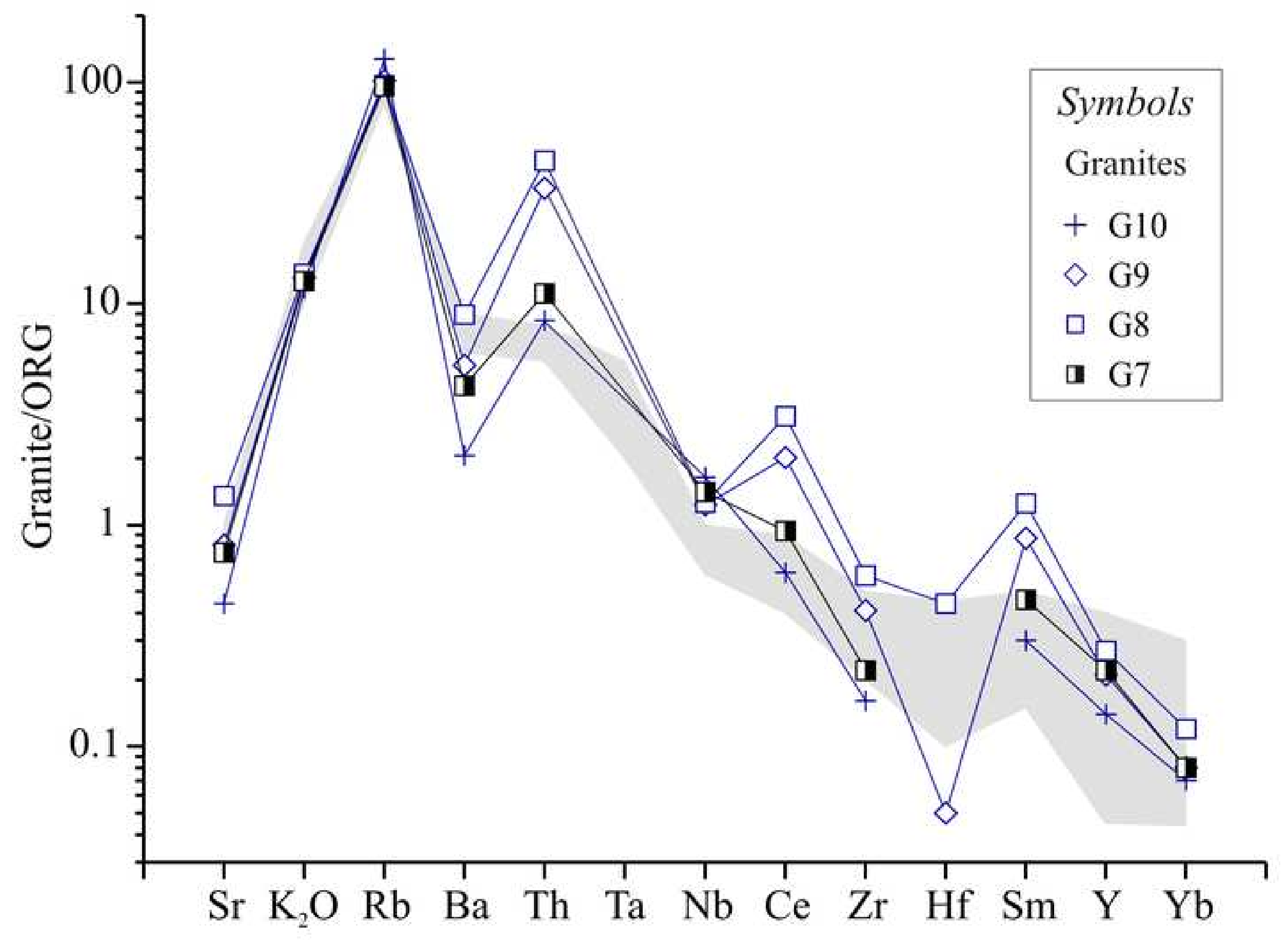



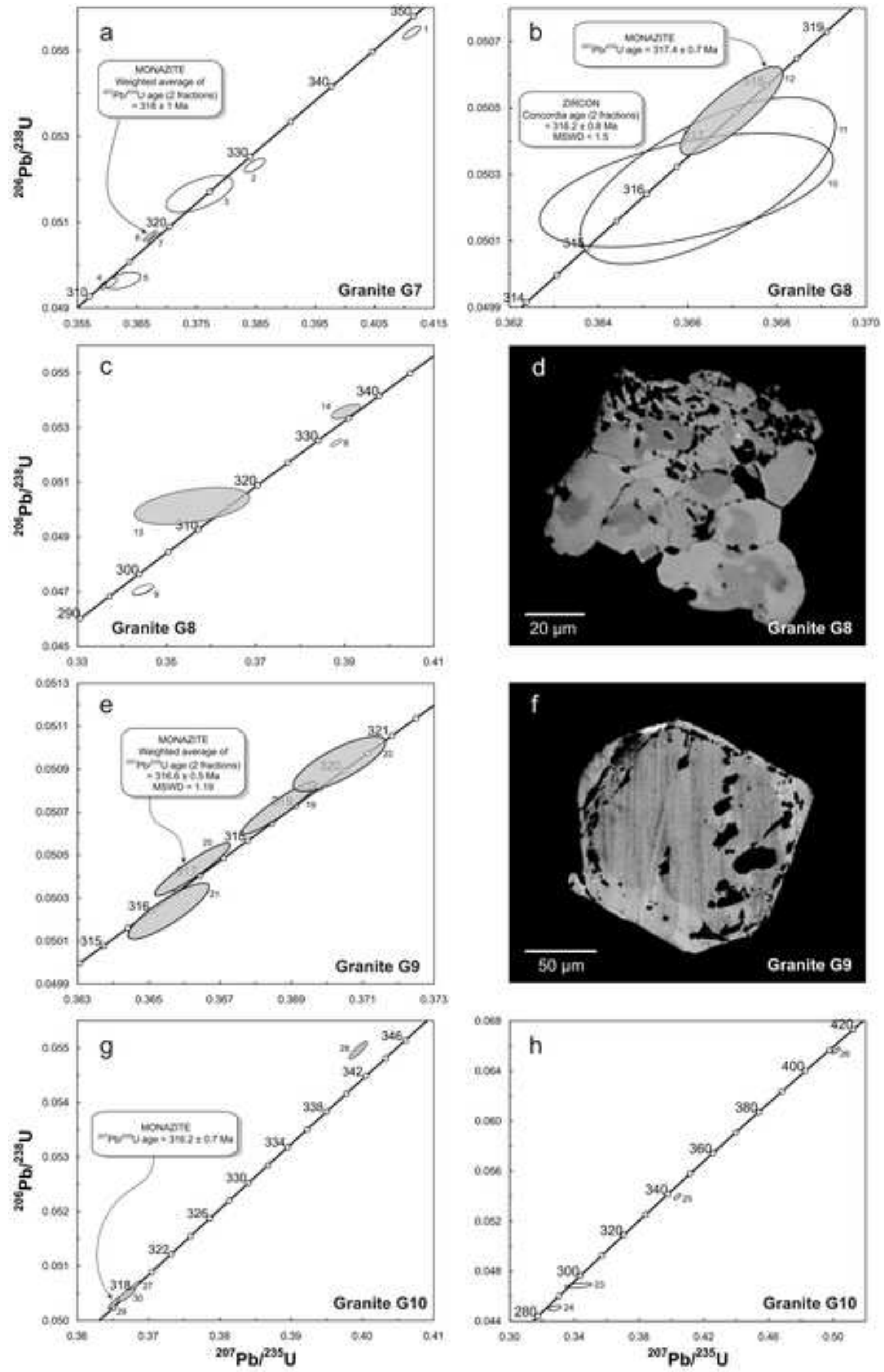
Click here to access/download;Figure;Fig 7 JIG.tif $\underline{\underline{\underline{\Perp}}}$

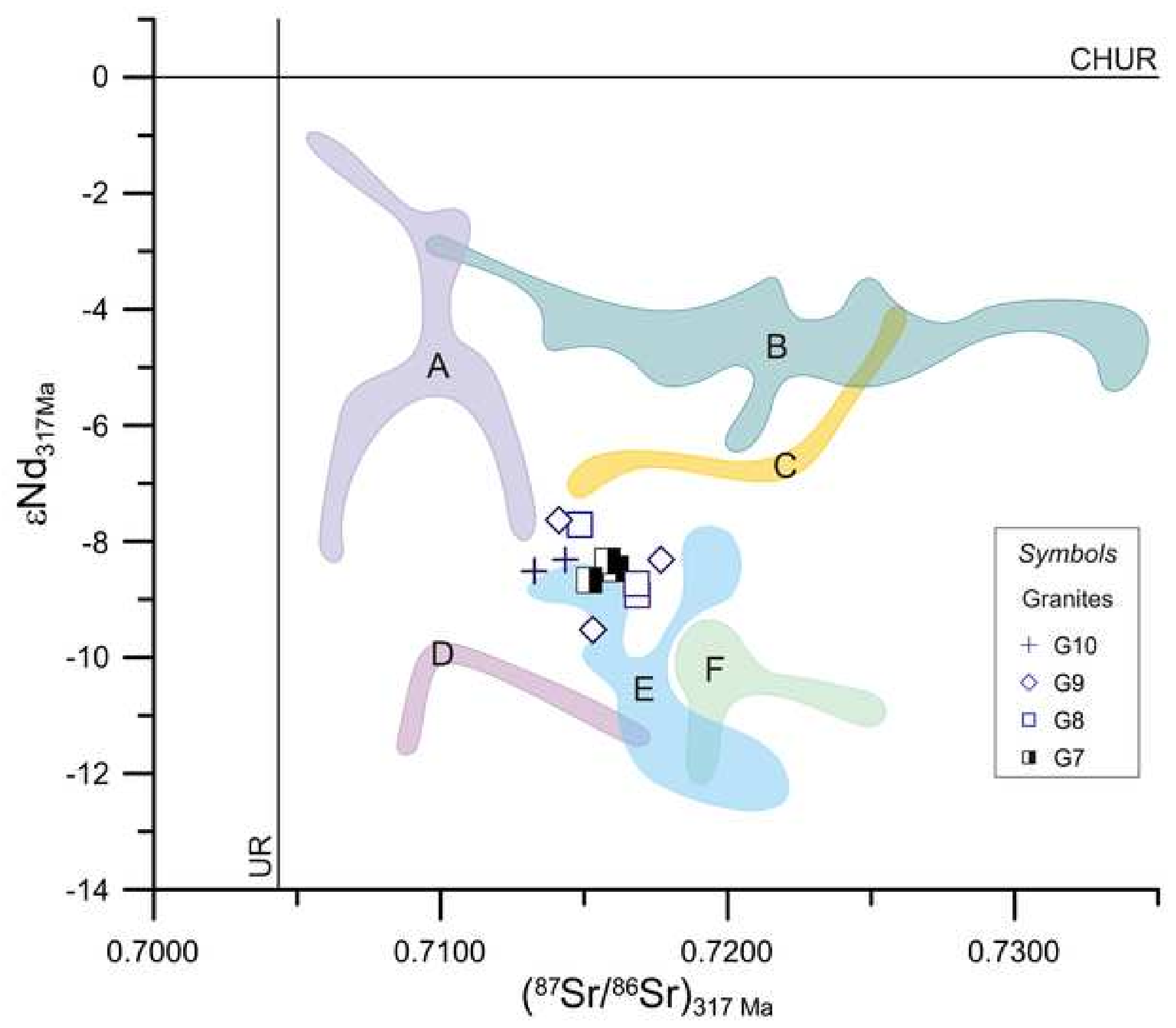




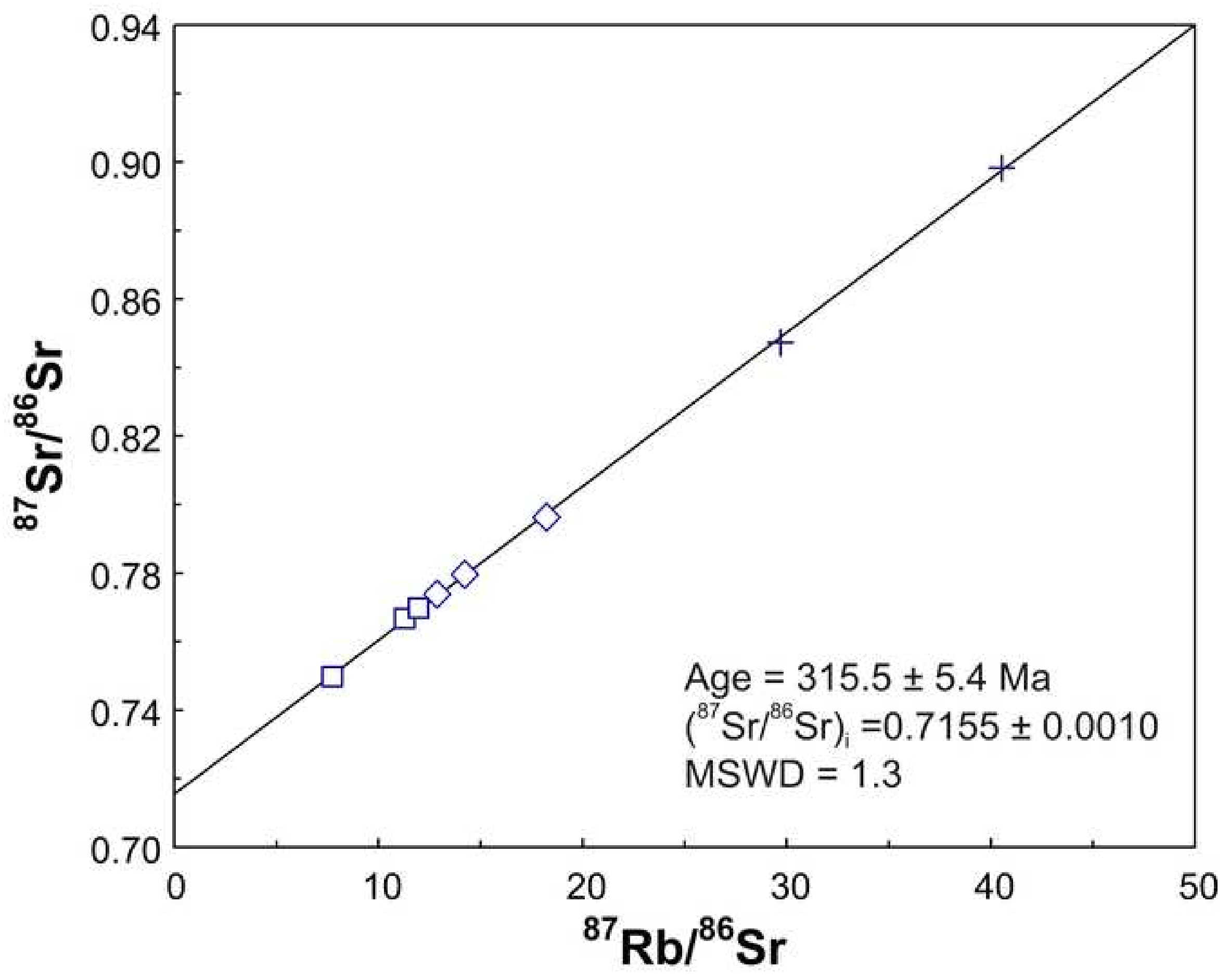



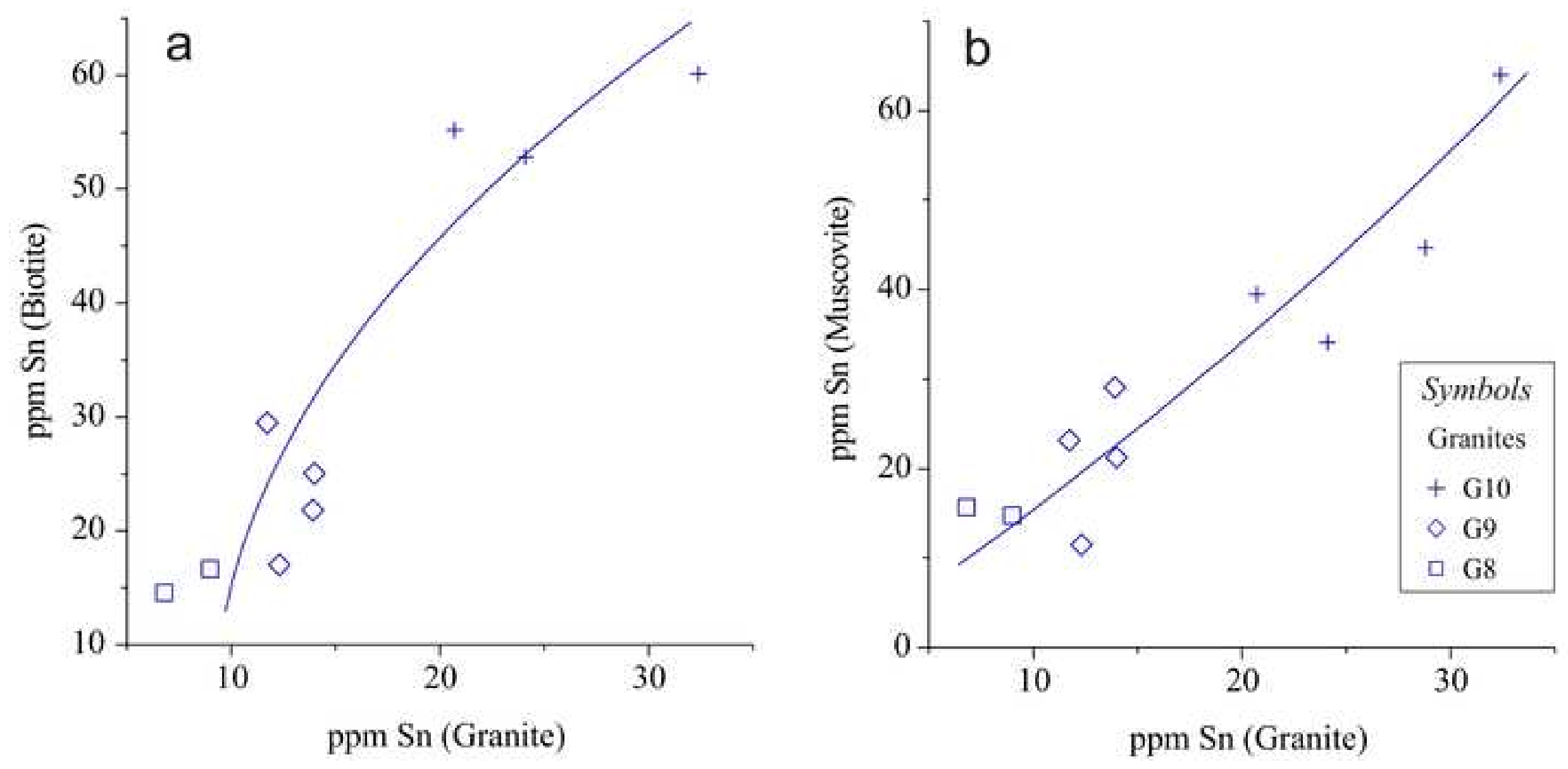


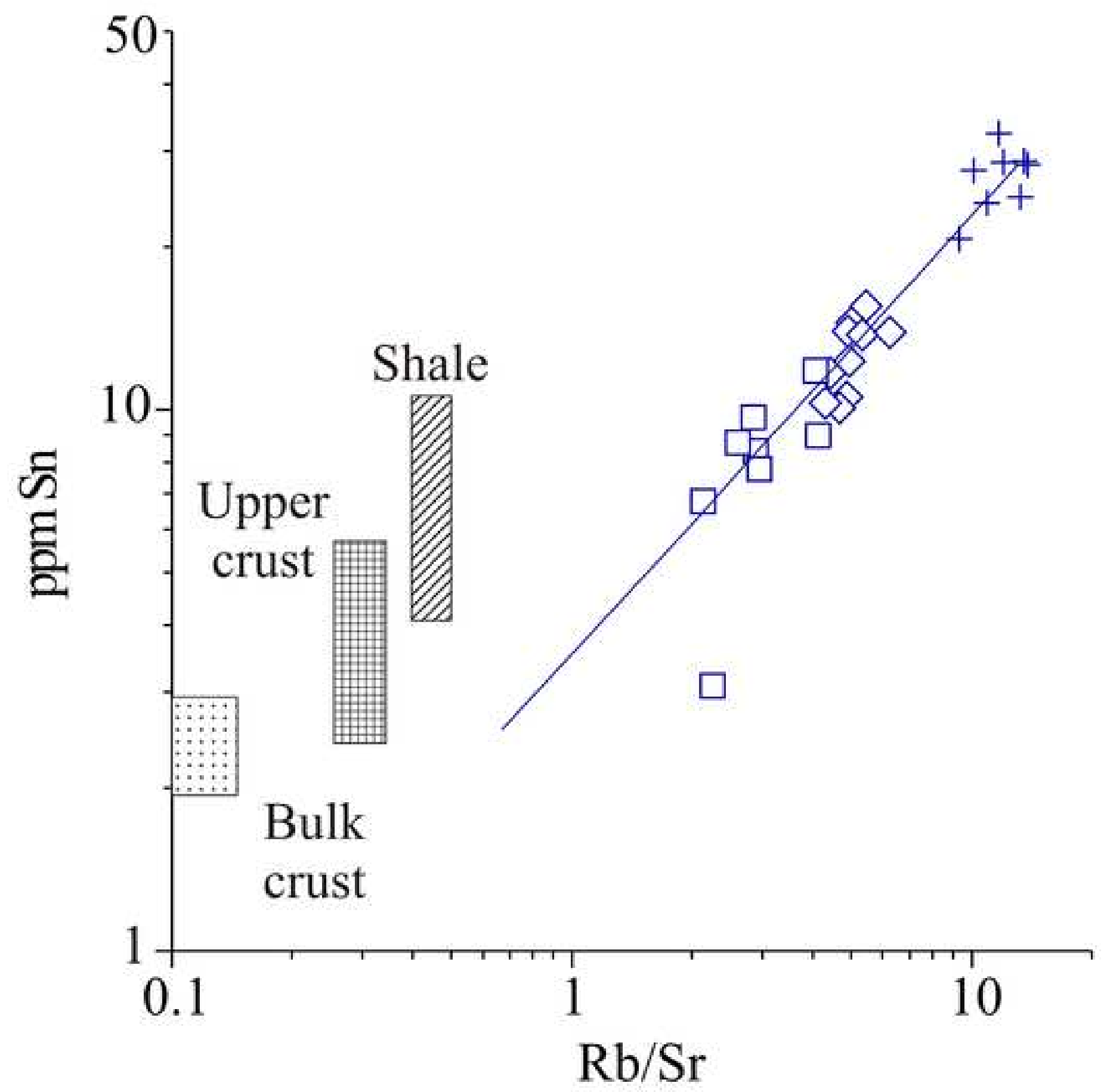


Click here to access/download Supplementary Material SedTable 1 rev.pdf 
Click here to access/download Supplementary Material SedTable 2.pdf 
Click here to access/download Supplementary Material SedTable 3.pdf 
Supplemental electronic data Table 4

Click here to access/download Supplementary Material SedTable 4.pdf 
Click here to access/download Supplementary Material SedTable 5 rev.pdf 
Click here to access/download Supplementary Material SedTable 6.pdf 
Click here to access/download Supplementary Material Supplemental electronic Fig. 1 JIG.tif 
Supplemental electronic Fig. 2

Click here to access/download Supplementary Material Supplemental electronic Fig. 2 JIG.tif 
Supplemental electronic Fig. 3

Click here to access/download Supplementary Material Supplemental electronic Fig. 3 JIG.tif 
Supplemental electronic Fig. 4

Click here to access/download Supplementary Material Supplemental electronic Fig. 4 JIG.tif 